\title{
Changes in tree species richness, stand structure and soil properties in a successional chronosequence in northern Chiloé Island, Chile
}

\author{
Cambios en la riqueza de especies arbóreas, estructura de rodales y propiedades del \\ suelo en una cronosecuencia sucesional en el norte de la Isla de Chiloé, Chile
}

JUAN C. ARAVENA, MARTÍN R. CARMONA, CECILIA A. PÉREZ1 \& JUAN J. ARMESTO1.2

\author{
${ }^{1}$ Laboratorio de Sistemática y Ecología Vegetal, Facultad de Ciencias, Universidad de Chile, \\ Casilla 653, Santiago, Fundación Senda Darwin, Ancud, Chiloé \& \\ Centro de Estudios Avanzados en Ecología y Biodiversidad, Chile \\ ${ }^{2}$ Corresponding author: e-mail: Jarmesto@uchile.cl
}

\begin{abstract}
We studied a chronosequence of forest fragments in northern Chiloé Island, southern Chile, with the aim of assessing ecosystem recovery patterns following anthropogenic disturbance. Hypotheses regarding successional trends in tree species richness, the replacement of shade-intolerant by shade-tolerant species, and the impact of disturbance on soil properties were evaluated in nine forest stands. The chronosequence encompassed two early (minimum stand age $<15$ years), three mid-successional (30-60 years), three late-successional (129-134 years), and one old-growth stand (ca. 200 years). Stand ages were estimated by coring a minimum of 30 canopy trees in each stand. Early and mid-successional stands showed evidence of human disturbance by fire of moderate intensity, with few scattered old trees surviving the fire. We determined densities and basal areas of all trees in a $50 \times 20 \mathrm{~m}$ plot, and densities of saplings and seedlings in subsamples of each plot. Soil $\mathrm{pH}$, total carbon $(\mathrm{C})$ and nitrogen $(\mathrm{N})$ contents, available $\mathrm{N}$, and bulk density were used to characterize soil processes across the chronosequence. In contrast to the hypothesis that predicts a decline in tree species richness during the course of succession due to competitive exclusion of pioneers, species richness of canopy trees increased from 3 to 13 through the chronosequence. This trend was accompanied by a more even distribution of species importance values in late succession. Changes in richness were unrelated to stem densities, which were highest in mid-successional forests. The number of species of woody seedlings and saplings did not change with stand age. Most tree species, both shade tolerant and intolerants, were present as seedlings in all the stands, but canopy dominance shifted from shade-intolerants in early and mid-successional forests to shade-tolerant species in late-successional and old-growth stands. We did not observe a complete replacement of these two groups of species, as shade-intolerant trees were still present in the canopy and/or understory of older stands. The successional trend fits Egler's Initial Floristic Composition Model, whereby differences in life history attributes among tree species account for major changes in dominance through succession. Soil properties were generally similar across the chronosequence of stands, suggesting that both ecosystem processes and tree regeneration were fairly resilient to moderate-intensity fire. We conclude that because of the relatively short history of human impact in the area, largely limited to the $20^{\text {th }}$ century, and the carry over of structural elements such as snags, logs, and large living trees in disturbed stands, lowland forest patches in northern Chiloé show resilience to human disturbance. However, as forests in the area become increasingly isolated, affected by recurrent fire, and other forms of human impact, their ability to recover their original structure and biodiversity will probably be impaired. Threshold levels of deforestation, at the landscape scale, that would impinge on successional trends at the patch scale remain an important open question for land managers.
\end{abstract}

Key words: forest succession, fire disturbance, biodiversity, shade tolerance, forest dynamics.

\section{RESUMEN}

Estudiamos una cronosecuencia de bosques sucesionales en el norte de la Isla de Chiloé, con el objeto de determinar sus patrones de recuperación luego de perturbación antrópica. Se evaluaron hipótesis referentes a las tendencias de cambio en la riqueza de especies arbóreas a lo largo de la sucesión, el reemplazo de especies sombra intolerantes por especies sombra tolerantes, y el impacto de la perturbación en las propiedades edáficas de estos fragmentos. Muestreamos nueve rodales, representados por dos bosques sucesionales tempranos (<15 años de edad mínima del rodal), tres rodales intermedios (30-60 años), tres avanzados (129-134 años), y un bosque antiguo (ca. 200 años). Las edades mínimas fueron estimadas a través de muestras de incremento radial de al menos 30 árboles del dosel por rodal. Los rodales tempranos e intermedios mostraron evidencias de perturbación por incendios moderados, con unos pocos grandes árboles vivos remanentes. En cada rodal se establecieron parcelas permanentes de 50 x 20 m para determinar densidades y áreas basales de árboles, con subparcelas interiores para estimar densidades de brinzales y plántulas. Para caracterizar los procesos edáficos en los rodales se determinó el $\mathrm{pH}$ del suelo, los contenidos totales de carbono (C) y nitrógeno $(\mathrm{N}), \mathrm{N}$ disponible y densidad aparente. En contraste con la hipótesis que predice una disminución de la riqueza de especies arbóreas en rodales más antiguos, debido a la exclusión de especies pioneras, la riqueza de especies en el 
dosel aumentó de 3 a 13 a través de la cronosecuencia. Esta tendencia estuvo acompañada por una mayor homogeneidad en los valores de importancia de las especies en los rodales más antiguos. Los cambios en riqueza de especies no estaban relacionados con las densidades de cada rodal, las cuales fueron máximas en los bosques de edad intermedia. Por otro lado, el número de especies de plántulas y brinzales no cambió con la edad del rodal. La mayoría de las especies arbóreas, tanto tolerantes como intolerantes a la sombra, se encontraban presentes como plántulas en todos los rodales. Las especies sombra-tolerantes tienden a reemplazar a las especies sombra-intolerantes en los bosques de edad más avanzada. No se observó un reemplazo completo de estos dos grupos de especies, ya que los árboles sombra-intolerantes estaban presentes en el dosel y/o en el sotobosque de los rodales antiguos. Este patrón sucesional se ajusta al modelo de Composición Florística Inicial de Egler, en el cual diferencias interespecíficas en los atributos de historia de vida darían cuenta de los principales cambios en dominancia durante la sucesión. Las propiedades del suelo fueron similares a través de la cronosecuencia, lo que sugiere que tanto los procesos ecosistémicos como la regeneración arbórea fueron capaces de recuperarse luego de incendios de intensidad moderada. Concluimos que, debido a la breve historia de impacto humano en el área, limitada principalmente al siglo 20, y a la persistencia post-perturbación de algunos elementos estructurales tales como detritus leñoso y grandes árboles vivos, los bosques en el norte de Chiloé se recuperan del impacto humano. En la medida en que aumente el aislamiento de los bosques remanentes, junto con la recurrencia de incendios u otras formas de impacto humano, su capacidad para recuperar su estructura y biodiversidad original debería disminuir. Los umbrales de deforestación y alteración de rodales a escala del paisaje que pueden alterar las tendencias sucesionales a la escala de los fragmentos de bosque constituyen una importante pregunta abierta.

Palabras clave: sucesión, incendios, biodiversidad, tolerancia a la sombra, dinámica forestal.

\section{INTRODUCTION}

Temperate rainforests of southern South America occur along a narrow but extensive latitudinal band between 37 and $55^{\circ} \mathrm{S}$, along the western margin of the continent (Fig.1). One of the most remarkable ecological attributes of these rainforests is their strong biogeographical isolation, which dates back to the mid Tertiary (Villagrán \& Hinojosa 1997). This long period of geographic isolation has resulted in unusually high levels of endemism both at the species and higher taxonomic levels (Armesto et al. 1996a, Arroyo et al. 1996, Villagrán \& Hinojosa 1997). In addition, south temperate rainforests exhibit a high productivity, with one of the greatest accumulations of standing biomass in temperate forests (over 1,000 tons ha-1), high stem densities (up to 10 thousand stems $\mathrm{ha}^{-1}$ ), and fast regeneration following disturbance (Armesto et al. 1996b). Their floristic richness is considered to be the highest among evergreen temperate rainforests worldwide (Arroyo et al. 1996). They include a broad array of plant life forms, some of which are rare or lacking in other high-latitude forests. For instance, more than 50 species of vascular epiphytes and vines are found in austral rain forests (Arroyo et al. 1996). Canopy trees support a richness of moss and lichen species that may be one of the highest among temperate forests (Galloway 1996). In montane forests of Chiloé Island biomass of vascular and non-vascular epiphytes has been estimated in 8 tons ha-1 (J. Armesto et al. unpublished results).

Considering their unique flora and fauna, high endemism, geographic isolation, and present human impact, Chilean temperate rain forests have been recognized as globally important and threat- ened ecosystems (Olson \& Dinerstein 1998, Myers et al. 2000). The major threats to southern temperate forests today are land clearing for agriculture, lack of sustainable management practices, massive timber extraction for wood chip production, and large-scale replacement of native forests by commercial monocultures of exotic trees (Lara et al. 1996, Armesto et al. 1998, 2001a). Impacts associated with land use have led to the rapid loss of old-growth forest habitat and increasing fragmentation and isolation of remaining forests (Willson \& Armesto 1996). Conspicuous components of forest biodiversity, such as endemic understory birds and cavity nesters have been shown to decrease in diversity and abundance in small forest fragments (Willson et al. 1994). The loss of structural elements of oldgrowth forest habitat such as large living trees, $\log s$ and snags in young stands seems to account for much of the decline in bird species richness (Willson et al. 1994, J. Armesto \& I. Díaz unpublished results). The lower volume of decaying woody residues in young, growing stands may also have negative impacts on other components of biodiversity, such as invertebrates and fungi, as well as on critical ecosystems processes sustaining forest productivity, such as soil nitrogen (N) mineralization and non-symbiotic $\mathrm{N}$ fixation (Carmona et al. in press).

This work focuses on the changes in tree species richness and structure in regenerating stands of temperate rain forests after non-catastrophic fire and logging associated with human activities. Despite the widespread use of fire to open land for farming and grazing pastures, and the extensive area of successional forests derived from such disturbance in southern Chile (e.g., CONAFCONAMA-BIRF 1999), there is a lack of studies 
of the changes in ecosystem functions, structure, and biodiversity as a consequence of human impacts. As discussed above, knowledge of the magnitude and direction of such structural and functional changes in Chilean forests is highly relevant to assess the potential of human-managed landscapes to sustain a desirable level of biodiversity and ecosystem production. Such applied knowledge is even more relevant considering that areas of high biodiversity and endemism are poorly protected within the regional park and reserve system (Armesto et al. 1998).

We assembled a chronosequence of successional stands, from recently burned to old-growth forest patches in a rural landscape in northern Chiloé Island, southern Chile (Fig. 1), in order to assess changes in ecosystem properties with stand age. We asked the following specific questions about the structure and dynamics of forests in this area: (1) how do tree species richness and dominance (density and basal area) change across the successional chronosequence in northern Chiloé forests?, (2) how does regeneration change for shade tolerant and intolerant tree species in successional forests of different ages?, (3) what are the major differences in stand structure and soil properties between young forests and old-growth forests?, and (4) what are the potential implications

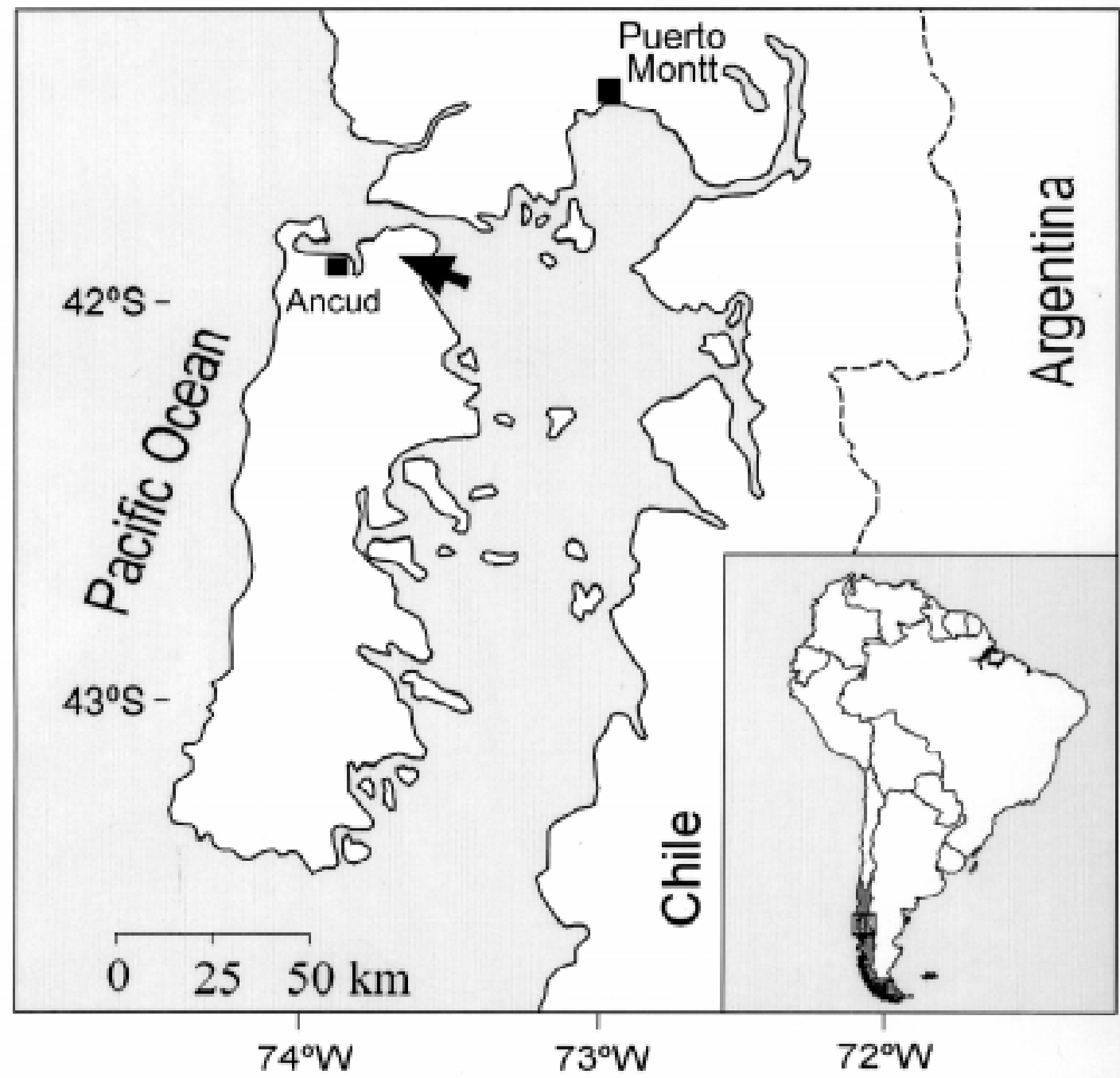

Fig. 1: Location of the study area in Chiloé Island. Arrow indicates the geographic position of "Senda Darwin" Biological Station. The forest fragments studied were located within a $20 \mathrm{~km}$ radius of the field station. Inset map shows the geographic distribution of South American temperate rainforests (shaded area).

Mapa de ubicación del área de estudio. La flecha indica la posición geográfica de la Estación Biológica Senda Darwin. Los bosques estudiados se encuentran a menos de $20 \mathrm{~km}$ alrededor de la estación biológica. En el mapa inserto se muestra también la distribución geográfica de los bosques templados lluviosos de Sudamérica (área sombreada). 
of these differences between second-growth and old-growth forests for the conservation of biodiversity and ecosystem function in humanmanaged landscapes?

Several hypotheses have been advanced that predict trends in species richness during forest succession. Most studies suggest that species richness should initially increase to a maximum due to immigration following disturbance, and later decline in response to interspecific competition for light and nutrients; consequently, species richness should peak in intermediate successional stages (Grime 1979, Huston 1994). These general hypotheses do not take into account inter-specific differences in tree life cycles, associated with shade tolerance and growth rates, which could alter these predictions (Huston \& Smith 1987, Picket et al 1987). We argue here that differences in growth rates among colonizing tree species (both shade-tolerant and intolerant) should drive successional changes and lead to increased tree species richness in older forests because of the coexistence of species with different life cycles in an increasingly heterogeneous light environment. An alternative prediction is that shadetolerant species should replace (or exclude) shadeintolerant trees in advanced stages of succession leading a decline in species richness (e.g., Tilman 1982, 1988). If tree species richness drops during succession due to the advantage of shade-tolerant, competitively dominant tree species, we expect that older forest stands will become speciespoor and more similar to one another in canopy composition than stands representing earlier successional ages. Finally, we will examine the hypothesis that non-catastrophic fire alters ecosystem functions due to the initially high loss of organic matter and nutrients associated with the disturbance event (Likens \& Bormann 1996), leading to reduced nutrient availability in successional forests with respect to older forests.

\section{MATERIAL AND METHODS}

\section{Study area and site selection}

The study area comprises about $400 \mathrm{~km}^{2}$ in the north-eastern corner of Chiloé Island, about $20 \mathrm{~km}$ north of the city of Ancud (41 ${ }^{\circ} 50^{\prime}$ S, Fig. 1). The landscape can be characterized as rolling hills with altitudes ranging from 50 to $100 \mathrm{~m}$. Soils are generally thin $(<1 \mathrm{~m})$, originated from Pleistocenic moraine fields and glacial outwash plains, with often poor drainage. Lowland forests in the area have been logged since the early 1800's, but land clearing became more intense in the second half of the $20^{\text {th }}$ century. The present-day rural landscape is characterized by a mosaic of remnant forest fragments, woodlands, and grazing pastures. The major forms of human impact on forests during the last century have been selective logging of valuable timber trees, widespread use of fire to clear land for pastures, and increasing patch fragmentation (Willson \& Armesto 1996).

The prevailing climate is described as wettemperate with a strong oceanic influence (Di Castri \& Hajek 1976). Meteorological records (4 years) at Senda Darwin Biological Station $\left(45^{\circ}\right.$ $53^{\prime} \mathrm{S}, 73^{\circ} 40^{\prime} \mathrm{W}$ ) indicate an annual rainfall of 2,090 $\mathrm{mm}$ and a mean annual temperature of 12 ${ }^{\circ} \mathrm{C}$. Maximum monthly temperatures (January) are $16^{\circ} \mathrm{C}$ and minimum monthly temperatures (July-August) are $5^{\circ} \mathrm{C}$. Rainfall occurs throughout the year, but $64 \%$ of the precipitation is concentrated from April to September.

TABLE 1

Estimated minimum ages of forest fragments for northern Chiloé Island

Edades mínimas estimadas para fragmentos de bosque del norte de la Isla de Chiloé

\begin{tabular}{|c|c|c|c|c|c|}
\hline $\begin{array}{l}\text { Stand } \\
\text { name }\end{array}$ & $\begin{array}{l}\text { Stand } \\
\text { code }\end{array}$ & Successional stage & $\begin{array}{l}\text { Mean age of canopy } \\
\text { trees } \pm 1 \mathrm{SD}\end{array}$ & $\begin{array}{c}\text { Mean of } 10 \\
\text { oldest trees } \pm 1 \mathrm{SD}\end{array}$ & Oldest tree alive \\
\hline Q1 & ES1 & Early successional & $2 *$ & - & - \\
\hline SD1 & ES2 & Early successional & $11 \pm 2$ & $11 \pm 2$ & 14 \\
\hline Rap1 & MS1 & Mid-successional & $34 \pm 6$ & $40 \pm 3$ & 46 \\
\hline Rap2 & MS2 & Mid-successional & $51 \pm 58$ & $70 \pm 31$ & 329 \\
\hline $\mathrm{SD} 2$ & MS3 & Mid-successional & $62 \pm 44$ & $112 \pm 46$ & 200 \\
\hline SD3 & LS1 & Late-successional & $69 \pm 44$ & $129 \pm 22$ & 174 \\
\hline $\mathrm{AC}$ & $\mathrm{LS} 2$ & Late-successional & $80 \pm 42$ & $133 \pm 46$ & 234 \\
\hline K & LS3 & Late-successional & $69 \pm 56$ & $134 \pm 78$ & 336 \\
\hline SD4 & OG & Old-growth & $95 \pm 77$ & $199 \pm 50$ & 311 \\
\hline
\end{tabular}

*Known age since the last stand-devastating anthropogenic fire to the time of plot sampling 
In this rural landscape, we selected nine stands (Table 1) that represented a broad successional chronosequence, including forests that were disturbed in the last decades, fast-growing mid-successional stands, late-successional, and oldgrowth forests. Initial stand selection was based on visual assessment of the present condition of forests (e.g., stem densities, open vs. closed canopy, presence or absence of large emergent canopy trees, signs of fire disturbance or logging), accessibility from nearby roads, and the willingness of landowners to allow us work in their properties. Studies were conducted in forest patches varying from 10 to larger than 100 ha in size, separated from one another by areas of open pastures, but connected to each other by secondary scrubland vegetation. Patch size was unrelated to stand age, and because forests were interconnected with other patches, we did not consider area as a factor in the present study of successional trends. All forests, including late-successional stands, have been subjected to occasional grazing by cattle, mainly along the margins, and some canopy trees have been selectively harvested. Early and mid-successional stands were recovering from non-catastrophic anthropogenic fire and subsequent timber extraction, as indicated by the local presence of charcoal, woody detritus, and stumps. Few scattered large trees were retained in all disturbed forests, which gives the canopy a complex vertical structure. Most lowland forests in the area have been subjected to similar practices and their floristic affinity and similar soils support their inclusion in a single successional chronosequence. The chronosequence of sites was established by coring at least 30 canopy trees per plot and counting their annual growth rings (see below).

Stands were located at 50-100 m elevation, over fluvio-glacial soils with variable drainage and gentle slopes $\left(5-10^{\circ}\right)$. All forests were dominated by evergreen, broad-leaved trees, but included narrow-leaf conifers (Saxegothaea conspicua, Podocarpus nubigena). Floristically, they all belong to the North Patagonian forest type as defined by Veblen et al. (1983). Nothofagus nitida, Drimys winteri and Podocarpus nubigena were present in the canopy of all stands, except for one late-successional site that lacked Podocarpus and had some emergent individuals of Eucryphia cordifolia (Eucryphiaceae). Abundant regeneration of tree seedlings and saplings and abundant cover of the native bamboo Chusquea quila, especially under tree-fall gaps, characterized the understory of most stands. Shrubs were generally rare or absent from mid-successional and old-growth stands, except along edges.

\section{Plot sampling}

Between 1998 and 2000 we set up nine Permanent Plots (PPs) in an equal number of forest stands, four in "Senda Darwin" Biological Station, and five in private properties located less than $20 \mathrm{~km}$ away from the Biological Station. Stands represented a broad range of successional ages, associated with different times since non-catastrophic fire disturbance (see below).

For comparative purposes, rectangular plots of $50 \times 20 \mathrm{~m}$ ( $0.1 \mathrm{ha})$ were set up in all forests. All stems with a diameter $>5 \mathrm{~cm}$ at $1.3 \mathrm{~m}$ above the ground or breast height were tallied and measured. Each stem rooted inside the plot was marked with a numbered metal tag and the following information was recorded: (a) species name, (b) diameter at breast height $(\mathrm{dbh})$, (c) crown position ( 1 = emergent, above canopy height, with light from above and all sides; $2=$ dominant, in the canopy tier with light from above and only one side; 3 = co-dominant, canopy tier with light from above only; 4 = subcanopy, second tier directly under the canopy; $5=$ understory, below the subcanopy, permanently shaded), and (d) condition $(1=$ alive, healthy; 2 = alive, with crown damage or decapitated; 3 = alive, inclined or fallen; 4 = dead standing; $5=$ dead, inclined or fallen). Saplings were defined as all stems $>1.3 \mathrm{~m}$ in height but $<5 \mathrm{~cm}$ dbh. Saplings were also tagged, identified to species, and counted in a 10 x $50 \mathrm{~m}$ subplot, one randomly selected half of the larger 0.1 ha plot. Seedlings (sensu lato) were defined as all stems $<1.3 \mathrm{~m}$ height, and were counted and identified to species within twenty 2 $\mathrm{x} 2 \mathrm{~m}$ quadrats located randomly within the 0.1 ha plot. The location of each seedling quadrat was permanently marked for future surveys.

\section{Stand ages}

In each permanent plot, ten trees in each of the first three categories of crown position (approximately 30 samples per plot) were cored with a Suunto increment borer. Cores were obtained at about $30 \mathrm{~cm}$ from the base of the trunk or stem, transported to the lab, mounted, sanded using sandpaper of increasingly finer grain, and dated following the techniques outlined in Stokes \& Smiley (1968). The number of annual rings in each core that crossed the center was counted and considered as the tree's minimum age, without 
estimating the time necessary for each tree to reach coring height.

We constructed age frequency histograms for each stand (Fig. 2) in order to select the best statistical parameter representing the minimum stand age and to establish each stand's position in the chronosequence. For early and mid-successional (ES and MS) stands there was a unimodal, and roughly normal age distribution, and $>50 \%$ of the cored trees had a minimum age of $<50$ years. In contrast, late-successional and oldgrowth stands (LS, OG) were characterized by much broader and multimodal age distributions (Fig. 2). Consequently, we used two different criteria for assigning stand ages. In the case of ES and MS stands, we used the mean age of all cored trees as representative of stand age (Table 1). The mean age for some ES and MS stands may be slightly inflated because of the inclusion in the sample of potential outliers, which are remnant old trees that survived the last fire (Fig. 2). For LS and OG stands, in turn, the mean age of the 10 oldest trees was considered representative of stand age (Table 1). The decision to use two different criteria for assigning stand ages is justified by the following reasoning. If the mean of all cored trees were used to estimate the ages for all of the stands, this would seriously underestimate the age of late-successional and old-growth stands because of their non-normal frequency distributions and the presence of many tall young trees within canopy gaps (Table 1). If, in turn, the age of the 10 oldest trees were used to estimate the minimum age for all stands, this would overestimate the age for early and mid-successional forests because of the influence of outliers (Fig. 2, Table 1).

\section{Soil sampling}

Plots in each stand were surveyed during 1999 and 2000 to assess the variation in soil properties that can be attributed to the effects of disturbance history. For this purpose, surface soil samples (Ah horizon; 0-10 cm soil depth) were collected from six random points along two parallel transect lines inside each permanent plot. Samples were sieved through $2-\mathrm{mm}$ mesh size before analysis. The $\mathrm{pH}$ of the sample was determined electrometrically in a $1: 2$ soil to water suspension. Total carbon $(\mathrm{C})$ and Nitrogen $(\mathrm{N})$ contents as percentages of dry mass were determined after instantaneous combustion using a Carlo Erba NA2500 element analyzer. Total inorganic N (nitrate plus ammonium) was extracted with a $1 \%$ of $\mathrm{K} \mathrm{Al}\left(\mathrm{SO}_{4}\right)_{2}$ solution, and determined by means of fractionated micro distillation. Additionally, we collected six soil samples with a steel cylinder to determine gravimetrically their bulk density. This soil survey is part of a more detailed monitoring of successional trends in ecosystem processes associated with $\mathrm{N}$ cycling that will be discussed elsewhere. In this paper we present average values for one sampling season to identify trends in soil properties associated with stand age.

\section{Data analyses}

Forest structure was characterized in terms of stem density and basal area for all tree species. Tree regeneration was characterized by the density of saplings and seedlings in each stand. Changes in ecological importance of each tree

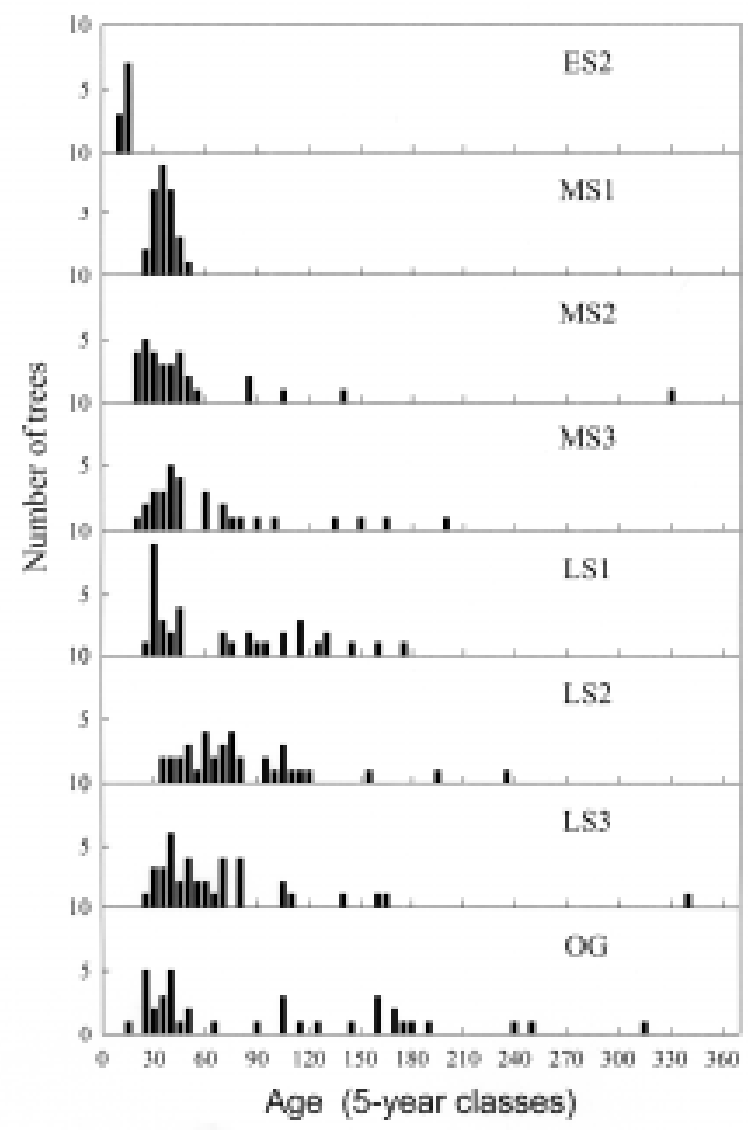

Fig. 2: Age structures of the nine successional stands arranged from the earliest successional plot (top) to the oldest stand (bottom). Site codes as in Table 1.

Estructuras de edad de los nueve rodales sucesionales ordenados desde el sucesionalmente mas temprano (arriba) hasta el mas tardío (abajo). Los códigos de los sitios según Tabla 1. 
species through the chronosequence were summarized by an Importance Value (IV), calculated as the sum of the relative basal area and relative density of each species. To quantify differences in the representation of ecological types or gross functional groups of tree species across stands in the successional chronosequence, we classified trees according to their shade tolerance (Table 2), based on previously published studies and personal observations. Shade-intolerant tree species are defined here as species that are always found as adults in open successional areas and are known to regenerate after catastrophic stand disturbance (Veblen \& Alaback 1996). Shade-tolerant trees, in turn, are generally absent as adults from open successional sites, but often form dense sapling "banks" in the shaded understory of secondgrowth and old-growth forests. They regenerate within small canopy openings originated by tree falls (Armesto \& Figueroa 1987, Veblen \& Alaback 1996). A third group of trees were classified as intermediate in shade tolerance because they are capable of regenerating in medium size tree-fall gaps as well as in large openings (Armesto $\&$ Fuentes 1988), but they rarely conform sapling banks.

Principal Component Analyses (PCA) of the successional stands were performed separately on the bases of (a) the relative importance values of canopy trees, (b) the relative densities of saplings, and (c) relative densities seedlings in PPs. Our goal was to assess whether differences among stands in species abundances and floristic composition of canopy trees and regenerating stems were related to stand's position in the chronosequence.

Shannon's diversity index was calculated for trees, saplings, and seedlings separately. This index assumes that individuals are randomly sampled and that all species are represented in the sample plot (Magurran 1988), which is a reasonable assumption in these low-diversity temperate forests. Shannon's diversity index was calculated by the equation:

$$
\mathrm{H}=\sum \mathrm{p}_{\mathrm{i}} \ln \mathrm{p}_{\mathrm{i}}
$$

where $p_{i}$ is the relative importance value or the proportion of individuals of the ith species in the sample plot.

\section{RESULTS}

\section{Chronosequence in relation to stand age}

Stands were initially selected and arranged to represent a putative successional (post-disturbance) gradient for lowland forests of the North Patagonian type, from young, recently regenerating stands, to old-growth forests. The successional gradient was confirmed by our analysis of minimum stand ages based on tree ring counts (Table 1), and by the comparison of the histograms of age structure for each stand (Fig. 2). Age distributions varied from

\title{
TABLE 2
}

\section{Classification of tree species in Chiloé forests according to shade tolerance (regeneration type)}

\begin{abstract}
Clasificación de especies arbóreas en bosques de Chiloé de acuerdo con la tolerancia a la sombra (tipo de regeneración)
\end{abstract}

\begin{tabular}{llll}
\hline Species & Family & Regeneration type & References \\
\hline Amomyrtus luma & Myrtaceae & Tolerant & Donoso (1989), Veblen \& Alaback (1996) \\
Amomyrtus meli & Myrtaceae & Tolerant & Donoso (1989) \\
Gevuina avellana & Proteaceae & Tolerant & Donoso (1989) \\
Laureliopsis philippiana & Monimiaceae & Tolerant & Donoso (1989), Veblen \& Alaback (1996) \\
Myrceugenia parviflora & Myrtaceae & Tolerant & Unpublished observations of the authors \\
Myrceugenia planipes & Myrtaceae & Tolerant & Unpublished observations of the authors \\
Podocarpus nubigena & Podocarpaceae & Tolerant & Veblen \& Alaback (1996) \\
Drimys winteri & Winteraceae & Intolerant & Donoso (1989) \\
Nothofagus nitida & Fagaceae & Intolerant & Donoso (1989) \\
Pseudopanax laetevirens & Araliaceae & Intolerant & Unpublished observations of the authors \\
Tepualia stipularis & Myrtaceae & Intolerant & Unpublished observations of the authors \\
Weinmannia trichosperma & Cunoniaceae & Intolerant & Donoso (1989) \\
Crinodendron hookerianum & Elaeocarpaceae & Intermediate & Veblen \& Alaback (1996) \\
Caldcluvia paniculata & Cunoniaceae & Intermediate & Donoso (1989), Veblen \& Alaback (1996) \\
Eucryphia cordifolia & Eucryphiaceae & Intermediate & Donoso (1989) \\
Saxegothaea conspicua & Podocarpaceae & Intermediate & Donoso (1989) \\
\hline
\end{tabular}


narrow, nearly even-aged for younger stands to multi-modal, spread distributions for older forests (Fig. 2). Therefore, this successional chronosequence included stands representing different stages of recovery following non-catastrophic human-set fire. Considering differences in age distributions among stands (Fig. 2), and evidence of past disturbance, the nine stands were arbitrarily grouped, for comparative purposes, into four categories: (a) early, (b) mid, (c) late-successional, and (d) old-growth. We describe below the general features and main differences in age, structure and composition among stands classified in each successional group. However, overall trends will be examined in relation to the entire gradient of stand ages (Table 3 ).

\section{Early successional stands}

Two stands were categorized as early successional (Table 1). In stand ES1, affected by anthropogenic fire two years earlier, most stems were standing dead, accounting for $97 \%$ of the total basal area (Table 3 ). This site had not been logged after fire, which is a common practice in Chiloé Island that may affect successional trends. Hence, much of the woody residues were still present at the site. The tree stratum was dominated by Drimys winteri and Amomyrtus luma (Table 4), with a few individuals of Podocarpus nubigena. Tree density was the lowest among all stands in the chronosequence (Table 3 ) because few living trees survived the fire. Sapling density was also low compared to other young and older successional stands, but seedling abundance was comparable to other forests in the area (Table 3 ).

Stand ES2 was cleared by fire and then logged at least 12 years before sampling according to minimum ages obtained from trees that were of sufficient height to be cored (Table 1). The main regenerating trees here were Nothofagus nitida and Drimys winteri (Table 4). As in stand ES1, basal area of standing dead individuals also represented a major proportion $(82 \%)$ of the total basal area of ES2, and tree density was still quite low (140 trees/ha, Table 3). Sapling density, however, was one of the highest in the chronosequence (Table 3), indicating that massive tree establishment followed disturbance. Seedling density was high and similar to the open stand ES1 (Table 3).

\section{Mid-successional stands}

In contrast to earlier successional sites, MS stands were set up under a fully closed canopy. Tree densities for some stands classified in this category were the highest in the chronosequence (Table 3 ). Stand MS 1 had a modal age of 39 years and was strongly even-aged, as indicated by the low variance for mean age of canopy trees (Table 1). The site presented evidence of past fire, suggesting that it was colonized within a narrow time interval, immediately following disturbance. Basal area of standing dead trees was much lower than in stands ES1 and ES2, but living stem density was two orders of magnitude higher than in the two early successional stands (Table 3). Despite this large difference in tree density, tree regeneration was also dominated by the pioneer trees Nothofagus and Drimys (Table 4). In this closed canopy stand, seedling density was the lowest in the entire chronosequence (Table 3). MS2 and MS3 were clearly dominated by Drimys winteri, a pioneer tree that was also abundant in early successional stands, but MS2 had an important presence of Eucryphia cordifolia (Table 4). An analysis of the age distribution of cored trees in plot MS2 (Fig. 2) indicates that few large individuals of Eucryphia are remnants of the original stand devastated by fire (see appendix). Stand MS2 seems to have been colonized later by Drimys and the other pioneer tree species. Nothofagus and Podocarpus were important species in the canopy of the young stand MS3 (Table 4), and this stand had the highest sapling density due to the abundant presence of shade-tolerant Amomyrtus luma (see Appendix 1).

\section{Late-successional stands}

Late successional stands (LS1-LS3) were characterized by broader age structures (Fig. 2). In all these cases, to use the mean age of all canopy trees clearly underestimated the age of the stand, because large emergent trees are important structural components of these forests (Fig. 2, Table 1). Their minimum age, estimated by the mean age of the 10 oldest trees, ranged between 129 and 134 years. Tepualia stipularis and Caldcluvia paniculata were more abundant in stand LS 1 than in all other stands (Table 4). Seedling densities were high for all late-successional stands (Table 3). Stand LS1 had the highest seedling density among all successional forests (Table 3), indicating a relatively more open canopy. Stand LS2 was dominated by Amomyrtus luma and Drimys winteri, whereas stand LS3 by Saxegothea conspicua and Nothofagus nitida. Consequently, late-successional stands were more heterogeneous with respect to canopy composition than earlier successional stands. Basal areas almost double 
FOREST SUCCESSION IN CHILOÉ ISLAND

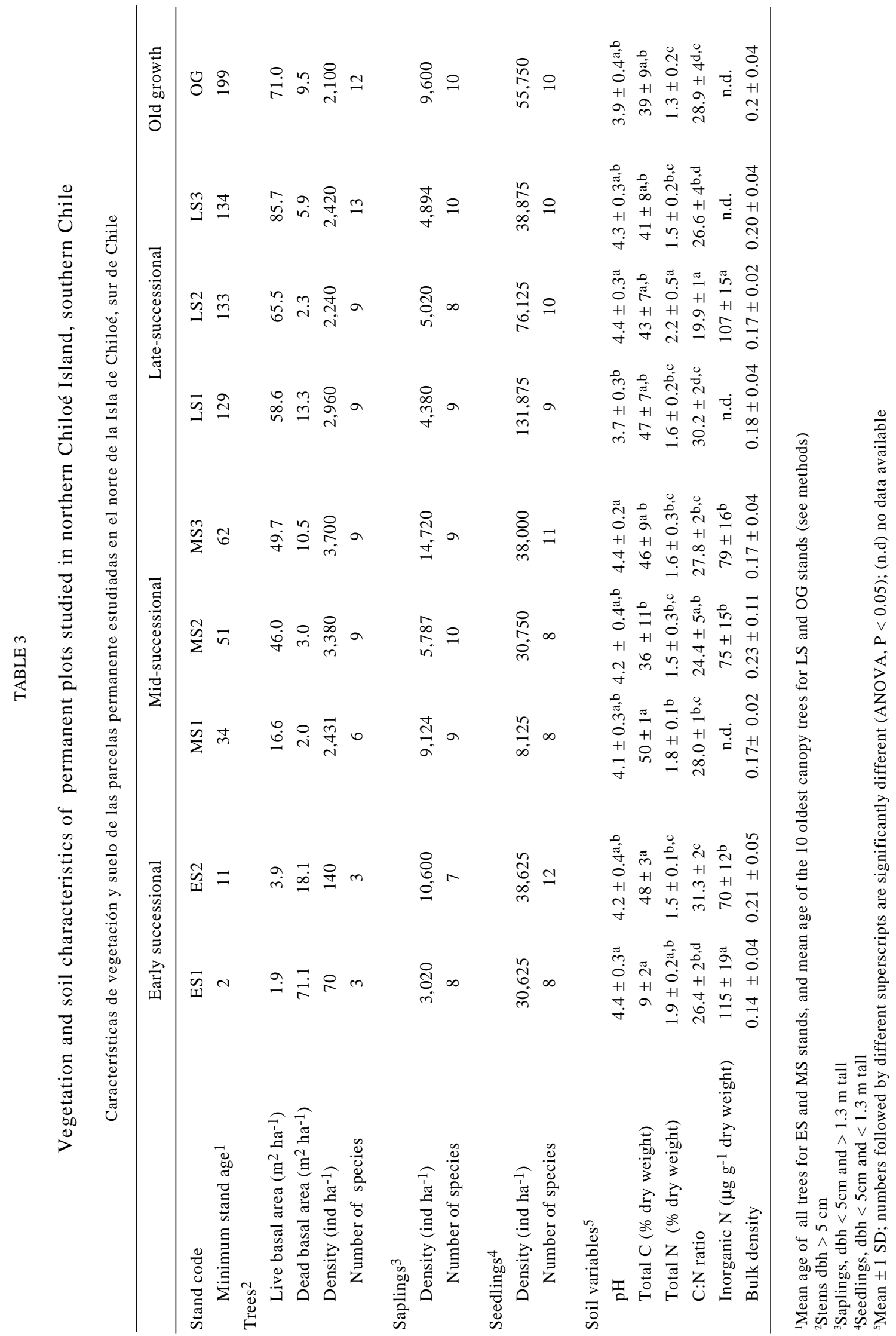


the values estimated for younger successional stands (Table 3), suggesting that late-successional stands are closer to the old-growth stage.

\section{Old-growth stand}

The last forest (plot OG) is nearly 200 years old, with no evidence of past fire and a tree density somewhat lower than mid and late-successional stands (Table 3 ). This site presented more evenly distributed importance values among canopy species, being Podocarpus nubigena and Tepualia stipularis the dominant tree species (Table 4). Basal area of living trees was high, but lower than for some late-successional stands (Table 3). Tree regeneration under the canopy was abundant, with relatively high densities of both saplings and seedlings (Table 3). Seedling density was higher than in all mid-successional stands.

\section{Trends in tree species richness with stand age}

The number of tree species increased almost linearly with stand age, reaching their higher values in the older stands $\left(r^{2}=0.74, \mathrm{P}<0.0004\right.$, Fig. 3A). Species in early-successional stands were a nested subset of species in late-successional and old- growth stands (Table 4), and hence older stands, taken together, contained all of the tree species represented in the successional chronosequence, including colonizing species. The only exception was Amomyrtus meli, which was only represented in one stand, MS2 (Table 4). However, this species was present as a sapling in older forests (Appendix 1). This trend of increasing tree species richness with successional age decreased in statistical significance or disappeared when we compared the number of species of saplings and seedlings across sites (Table $3 ; \mathrm{r}=0.67, \mathrm{P}<0.048$ for saplings, $\mathrm{r}=0.15, \mathrm{P}=0.71$ for seedlings). The site with the highest number of species of tree seedlings (12 species) was ES2, one of the early successional stands in the chronosequence (Table 3 ). Thus, while there was a linear increase in the number of tree species represented in the forest canopy as stands become older, the number of tree species represented as seedlings in the understory did not change through succession.

\section{Successional trends in basal area}

Similarly, total basal area of living trees increased significantly with successional age (Fig. 3B), approaching an asymptote in the older stands in the chronosequence. Basal area seems to level off

\section{TABLE 4}

Importance values (relative basal area + relative density) for tree species in a chronosequence of successional forests in Chiloé Island, southern Chile. Maximum value for each species is 200. Stand codes as in Table 1

\footnotetext{
Valores de importancia (área basal relativa + densidad relativa) para especies arbóreas en una cronosecuencia de bosques sucesionales in la Isla de Chiloé, sur de Chile. Valor máximo para cada especie es 200. Códigos de rodales de acuerdo a Tabla 1
}

\begin{tabular}{|c|c|c|c|c|c|c|c|c|c|}
\hline \multirow{3}{*}{ Species } & \multirow{2}{*}{\multicolumn{2}{|c|}{ Early successional }} & \multicolumn{6}{|c|}{ Forest stand } & \multirow{3}{*}{$\begin{array}{c}\text { Old-growth } \\
\text { OG }\end{array}$} \\
\hline & & & \multicolumn{3}{|c|}{ Mid-successional } & \multicolumn{3}{|c|}{ Late-successional } & \\
\hline & ES1 & ES2 & MS1 & MS2 & MS3 & LS1 & LS2 & LS3 & \\
\hline Amomyrtus luma & 59.6 & 0.0 & 0.0 & 24.7 & 20.6 & 3.3 & 75.6 & 21.7 & 5.8 \\
\hline Amomyrtus meli & 0.0 & 0.0 & 0.0 & 2.8 & 0.0 & 0.0 & 0.0 & 0.0 & 0.0 \\
\hline Crinodendron hookerianum & 0.0 & 0.0 & 0.0 & 0.0 & 0.0 & 6.8 & 1.0 & 0.5 & 6.4 \\
\hline Caldcluvia paniculata & 0.0 & 0.0 & 0.6 & 0.7 & 9.2 & 21.2 & 1.0 & 10.3 & 9.0 \\
\hline Drimys winteri & 110.1 & 95.4 & 82.9 & 105.4 & 81.8 & 15.2 & 65.2 & 31.5 & 31.9 \\
\hline Eucryphia cordifolia & 0.0 & 0.0 & 0.6 & 41.3 & 0.0 & 0.0 & 1.4 & 0.0 & 0.0 \\
\hline Gevuina avellana & 0.0 & 0.0 & 0.0 & 1.5 & 0.0 & 0.0 & 3.7 & 3.3 & 7.3 \\
\hline Laureliopsis philippiana & 0.0 & 0.0 & 0.0 & 3.9 & 0.0 & 0.0 & 36.1 & 4.4 & 3.3 \\
\hline Myrceugenia parviflora & 0.0 & 0.0 & 0.0 & 0.0 & 2.4 & 0.0 & 2.0 & 2.4 & 1.0 \\
\hline Nothofagus nitida & 0.0 & 72.7 & 88.7 & 16.4 & 33.9 & 35.9 & 14.0 & 41.3 & 15.6 \\
\hline Podocarpus nubigena & 30.2 & 0.0 & 0.0 & 0.0 & 36.4 & 35.4 & 0.0 & 16.8 & 44.7 \\
\hline Pseudopanax laetevirens & 0.0 & 0.0 & 5.3 & 0.0 & 3.7 & 0.0 & 0.0 & 0.6 & 0.0 \\
\hline Saxegothaea conspicua & 0.0 & 0.0 & 0.0 & 3.4 & 5.7 & 1.7 & 0.0 & 43.3 & 7.0 \\
\hline Tepualia stipularis & 0.0 & 0.0 & 21.8 & 0.0 & 6.3 & 69.3 & 0.0 & 13.2 & 36.1 \\
\hline Weinmannia trichosperma & 0.0 & 31.9 & 0.0 & 0.0 & 0.0 & 11.2 & 0.0 & 10.9 & 31.7 \\
\hline
\end{tabular}


around $70 \mathrm{~m}^{2} \mathrm{ha}^{-1}$ in 150 year old stands. Separating shade-tolerant from shade-intolerant tree species in these forests (Table 2), the asymptote of the curve of total basal area vs. stand age seems to be due entirely to shade-intolerant species (Fig. 3C). The relationship between basal area and stand age for shade-tolerant species, on the other hand, was still increasing for older stands, with a best fit to a linear model (Fig. 3C).

\section{Successional trends in regeneration}

Total density of saplings and seedlings did not show consistent trends in successional stands (Table 3), except that older stands generally had greater numbers of seedlings than early and mid-
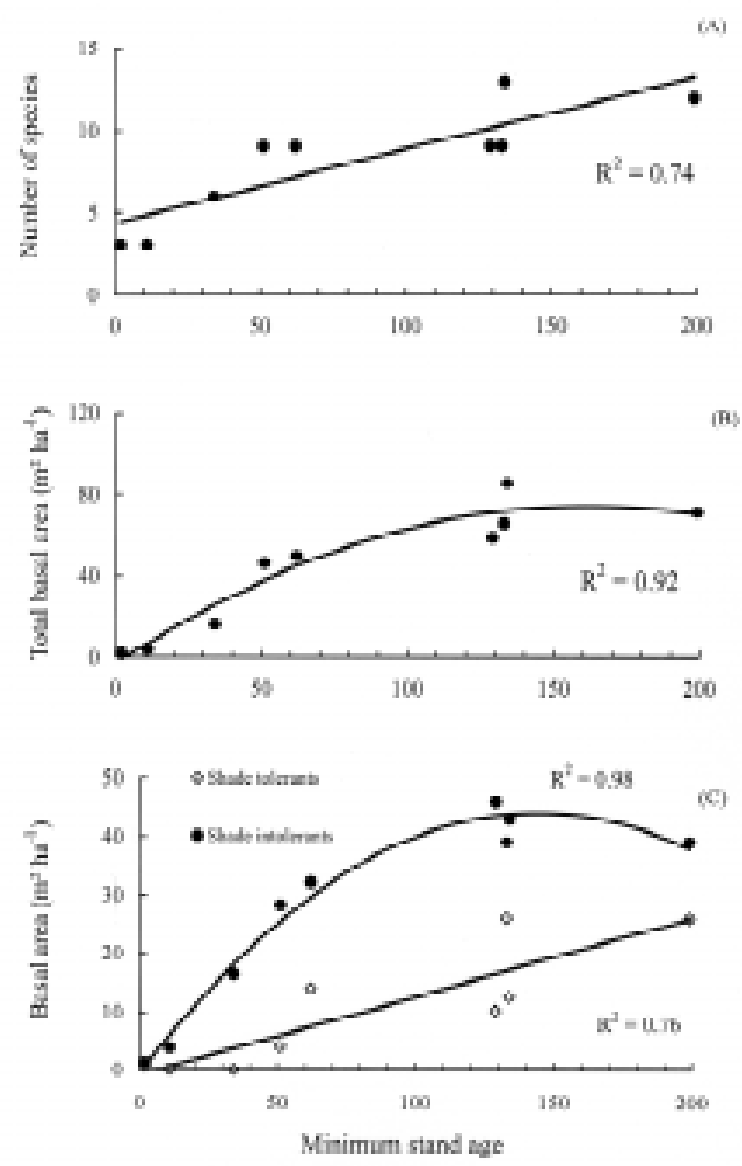

Fig. 3: Relationship between minimum stand age and (A) number of tree species, (B) basal area for all tree species, and (C) basal area for shadetolerant and intolerant tree species separately.

Relación entre la edad mínima del rodal y (A) número de especies arbóreas, (B) área basal para todas las especies arbóreas, y (C) área basal para especies arbóreas tolerantes e intolerantes a la sombra separadamente. successional stands. However, a closer inspection of sapling and seedling densities (Appendix 1) shows that the relative importance of different tree species changed greatly during the chronosequence. For sapling density, dominance shifted from Nothofagus nitida and Drimys winteri in early and mid-successional stands to Amomyrtus luma, Podocarpus nubigena and other species in later-successional stands (Fig. 4A). Saplings of Drimys winteri remained relatively important only in the old-growth forest site (Fig. 4A).

For tree seedlings, patterns of change in dominance during succession were not as clear as for saplings (Fig. 4B), and for some species such as Drimys winteri, the tendency observed for saplings (Fig. 4A) was reversed for seedlings (Fig. 4B), that is, Drimys seedlings were more abundant in late-successional stands. The tendency for Amomyrtus luma and Podocarpus nubigena to increase in density in late-successional and oldgrowth stands was also observed for seedlings, although weaker (Fig. 4B). In contrast to the pattern for saplings, Nothofagus nitida was absent or relatively uncommon as seedling in all but one early successional stand, and Pseudopanax laetevirens, a species that was not present as either sapling or adult in any of the stands (Table 3 , Appendix 1) had conspicuous seedling densities across all successional ages (Fig.4B).

These changes in density of saplings and seedlings across sites reflect changes in the proportion of shade-intolerant and shade-tolerant tree species in the forests (Fig. 4C and 4D). In the younger successional stands, shade-intolerant species accounted for $60-90 \%$ of the saplings (Fig. 4C) and 40-70\% of the seedlings (Fig. 4D). Shade-tolerant and intermediate species showed a pronounced increase in relative importance among saplings in late-successional and oldgrowth stands (Fig. 4C). However, these differences were less pronounced for seedlings (Fig. 4D). In fact, shade-intolerant species still make up nearly $50 \%$ of all the seedlings in the three older stands, and up to $80 \%$ of seedlings in one late-successional stand (Fig. 4D). In contrast to saplings, the proportions of shade-tolerant and intolerant seedlings did not show a reciprocal replacement pattern related to stand age, and these proportions seem to vary widely according to particularities of each site.

Successional patterns of tree mortality and health condition

For trees $>5 \mathrm{~cm}$ dbh, patterns of mortality vary across sites in relation to stand age and shade 
tolerance attributes of the different species (Fig. 5). For the sake of simplicity, we illustrate these patterns for one stand in each of three successional stages, early, mid and late-successional (Table 1), taken as representative of their successional stage. Tendencies were approximately similar for those stands not shown. Most trees were dead standing in site ES1, which was recently disturbed by fire (Table 3); shade-tolerant and intolerant species were present in similar dbh groups, but shade-tolerant were generally in poor health condition compared to intolerant species (Fig. 5A and 5B). For stand MS3, most living trees were shade intolerant (Fig. 5C and 5D) and these trees had a broader dbh range $(10-50 \mathrm{~cm}$, median $=25 \mathrm{~cm})$ than shade-tolerant species $(10$ $40 \mathrm{~cm}$, median $=15 \mathrm{~cm}$ ). Both shade-tolerant and intolerant species show an increase in the propor- tion of individuals with crown damage in the first dbh class (Fig. 5C and 5D), relative to stand ES1 (Fig. 5A and 5B). Finally, in stand LS2, most individuals in healthy condition were shade-tolerant tree species (Fig. 5E), represented in the dbh classes $<45 \mathrm{~cm}$. The frequency distribution of shade-tolerant species by dbh class approaches a reverse-J distribution, which is indicative of a vigorously growing stand (Oliver \& Larson 1990). In contrast, shade-intolerant trees had a broader dbh range, characteristic of a decaying stand, with an important proportion of standing dead and sick individuals in the small and intermediate dbh classes (Fig. 5F). Hence, two different dbh structures were characteristic of late-successional stands (Fig. 5E and 5F), reflecting the contrasting patterns of growth and mortality of shade-tolerant and intolerant tree species.

\section{SAPLINGS}

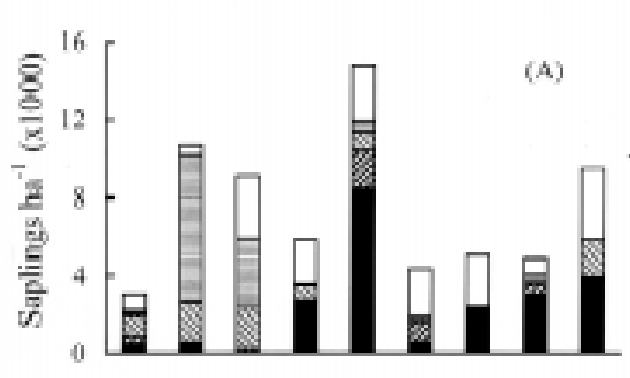

ES1 ES2 M1 M2 M3 LS1 LS2 LS3 OG

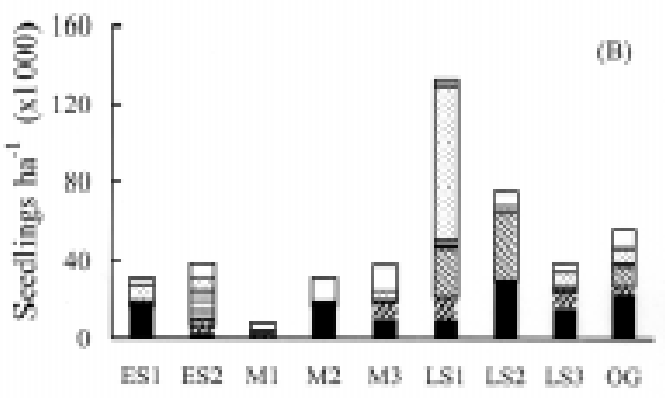

- al * * ondw $\square$ nn $\square$ pl $\square$ others

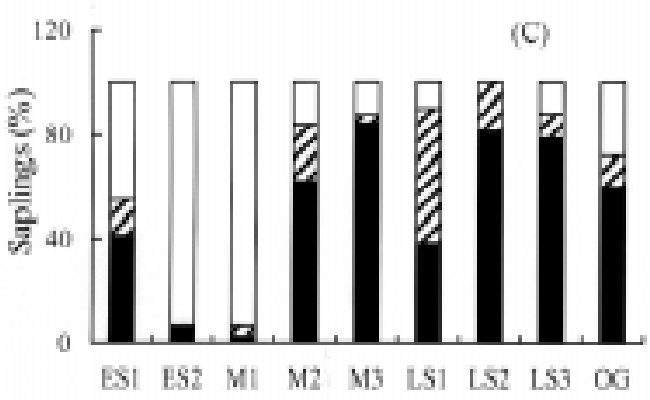

Minimum stand age

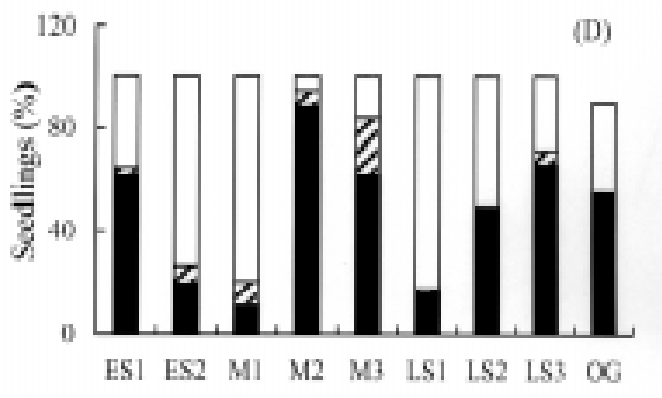

Minimum stand age

Tolerants $\mathbf{Z}$ Intermediates $\square$ Intolerants

Fig. 4: Changes in relative density of saplings (A, C) and seedlings (B, D) across the successional chronosequence. Data are presented sorted by tree species (A and B) and by shade tolerance groups (C and D). Codes for tree species are: $\mathrm{al}=$ Amomyrtus luma $; \mathrm{pn}=$ Podocarpus nubigena $; \mathrm{dw}=$ Drimys winteri $; \mathrm{nn}=$ Nothofagus nitida $; \mathrm{pl}=$ Pseudopanax laetevirens.

Frecuencia de juveniles y plántulas a lo largo de la cronosecuencia sucesional de acuerdo a la composición de especies arbóreas (A y B, respectivamente), y tolerancia a la sombra (C y D, respectivamente). Los códigos de las especies arbóreas corresponden $\mathrm{a}: \mathrm{al}=$ Amomyrtus luma $; \mathrm{pn}=$ Podocarpus nubigena $; \mathrm{dw}=$ Drimys winteri $; \mathrm{nn}=$ Nothofagus nitida $; \mathrm{pl}=$ Pseudopanax laetevirens. 


\section{Diversity indices}

Comparisons based on Shannon's diversity index for seedlings, saplings and trees separately, showed different patterns in relation to stand age (Fig. 6A, 6B, and 6C). While for seedling and saplings there was no clear tendency associated with the position of the stand in the chronosequence, species diversity of trees $>5 \mathrm{~cm}$ $\mathrm{dbh}$ increased from early successional stages to old-growth forests (Fig. 6A). This increase in diversity is consistent with the increase in the

\section{TOLERANTS}
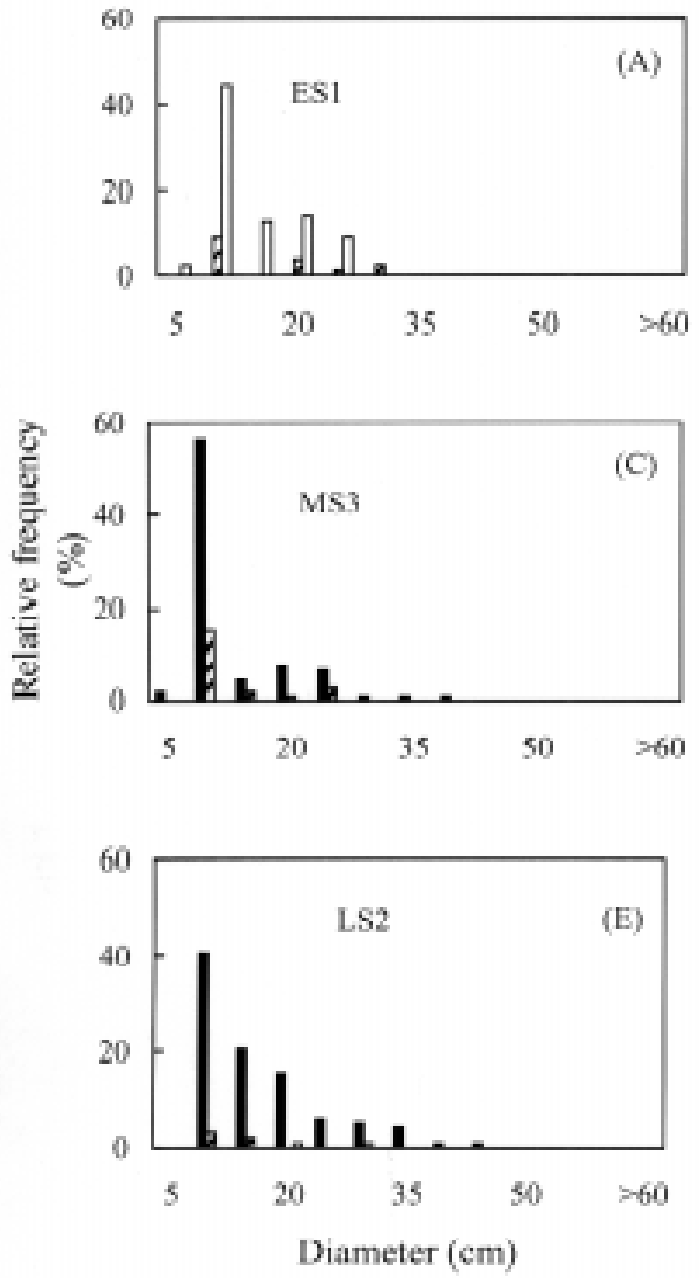

number of tree species observed through the chronosequence (Fig. 3A). A higher diversity index in old-growth stands results from the increasing canopy recruitment of shade-tolerant tree species, added to the persistence of shade-intolerant species with a relatively high importance value (Table 4). On the other hand, saplings and seedlings, show fluctuations in their diversity indices associated with changes in dominance by particular canopy species in different stands, suggesting that dominance levels are more responsive to local site conditions.
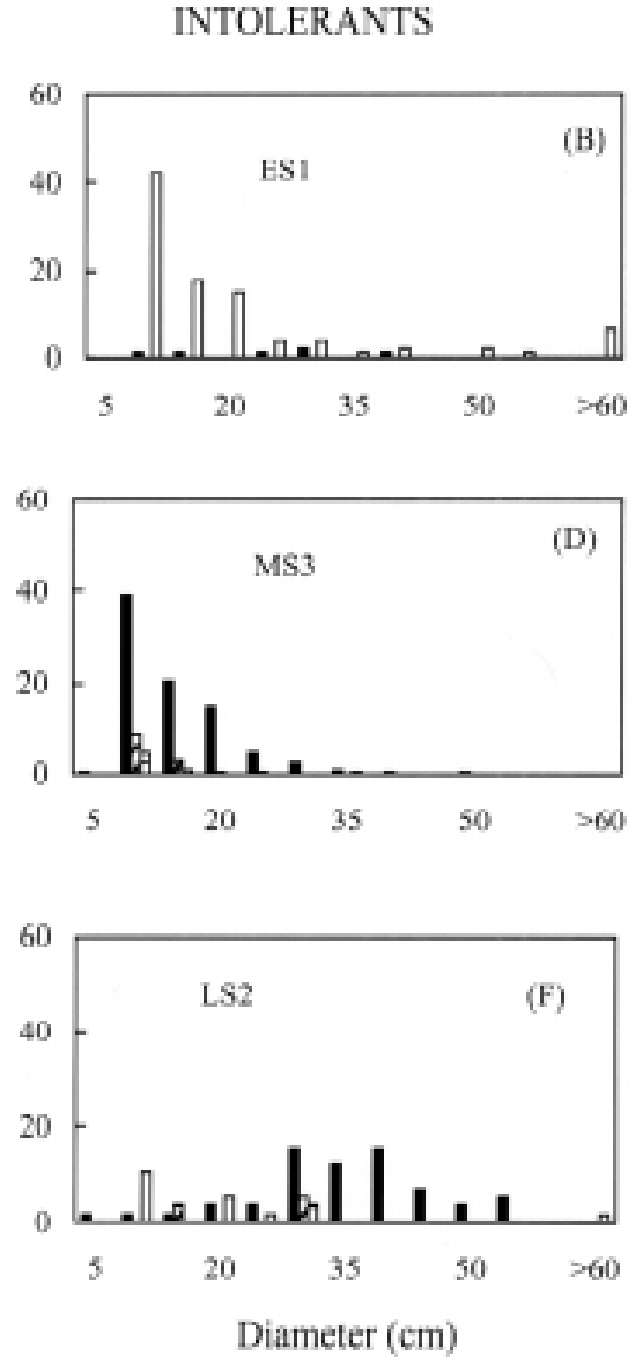

- Alive Ø Sick $\square$ Dead

Fig. 5: Size-frequency distributions (in 5-cm dbh increments) for shade tolerant (left hand side panel), and shade intolerant (right hand side panel) tree species in a stands ES1, MS3, and LS2, representing early, mid and late successional stages in a chronosequence of forests in northern Chiloé. Stems are classified by condition (see methods) in alive, sick, and standing dead.

Distribuciones de las frecuencias de tamaños (clases de $5 \mathrm{~cm}$ de dap) para especies arbóreas sombra tolerantes (primera columna) y sombra intolerantes (segunda columna), clasificadas según su condición sanitaria de los individuos (ver métodos), en las parcelas de estudio ES1, MS3 y LS2. 


\section{PCA ordination}

Principal component analysis of the tree stratum was used to illustrate the floristic affinity of successional plots in the chronosequence (Fig. 7). The first two components of the ordination concentrated $70 \%$ of total variance of the data. The distribution of plots along the first component
(PC1 axis, Fig. 7), which explained $50 \%$ of the variance, reflected roughly the separation between early and mid-successional from late-successional stands in the chronosequence. Early and midsuccessional stands presented a narrower range of values and all plots had values $>0.8$ for the first PCA axis (Fig. 7). In contrast, old-growth and late-successional stands in the
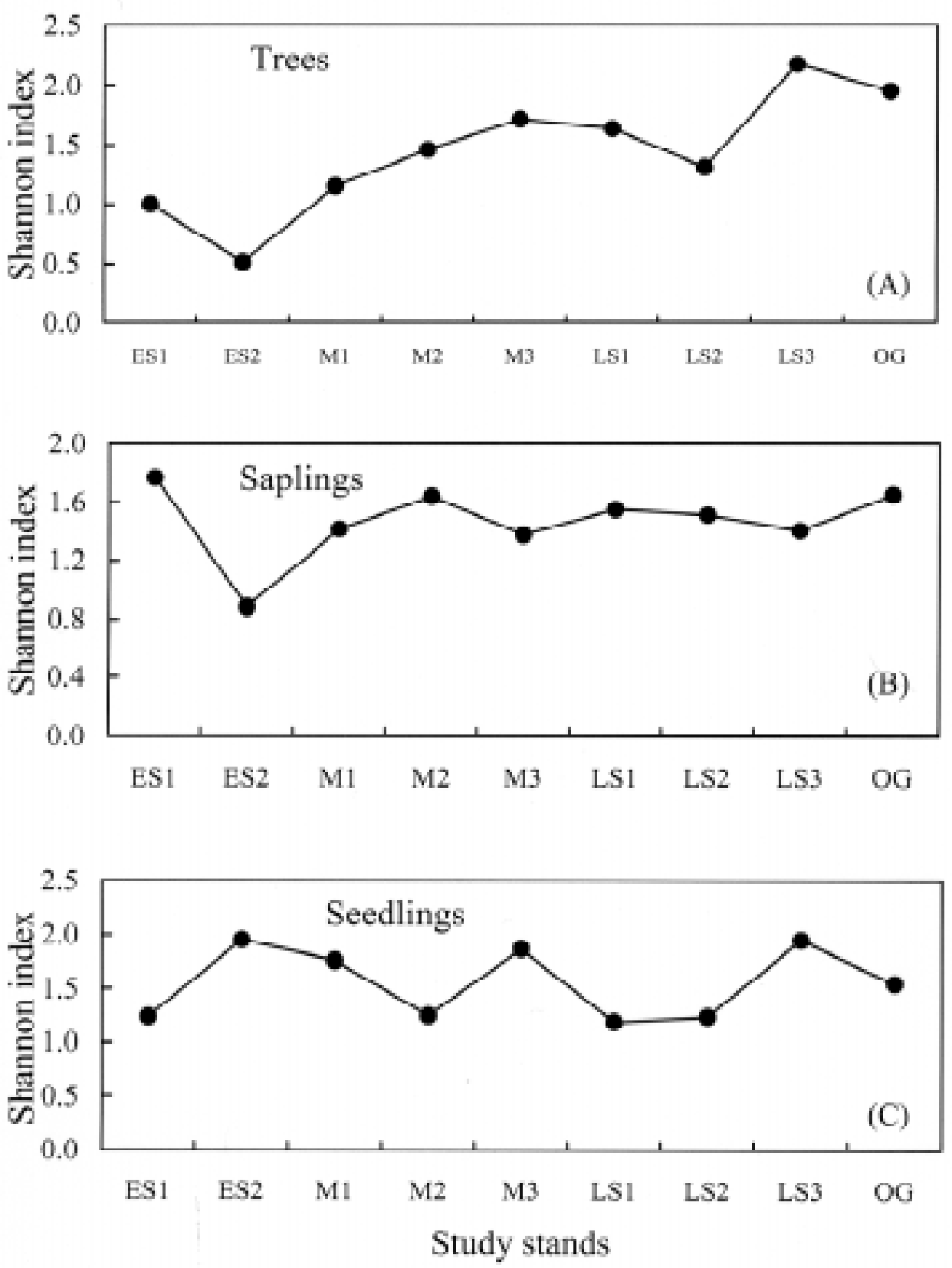

Fig. 6: Shannon diversity indices (see text) calculated for trees, saplings and seedlings along a successional chronosequence of forest stands in northern Chiloé Island. Stand codes as in Table 1.

Indices de diversidad de Shannon para árboles, brinzales y plántulas a lo largo de la cronosecuencia sucesional de rodales en el norte de la isla de Chiloé. Códigos de los rodales de acuerdo a la Tabla 1. 
chronosequence had values $<0.7$ for the first PCA axis. The first component of PCA did not discriminate between early and mid-successional stands, based on the importance values of tree species. However old-growth and latesuccessional forests spread widely along the second PCA axis. Separation along the second axis reflects major floristic differences in the tree stratum among these forests, which seem unrelated to stand age. The broader range of differentiation for old-growth and late-successional forests on the second PCA axis was greater than for early and mid-successional stands (Fig. 7). Accordingly, this result suggests that old-growth and latesuccessional stands tend to develop a greater heterogeneity in canopy composition than younger stands in the chronosequence.

The positions of sampling plots in PCA axes based on the densities of tree saplings and seedlings (data not shown), analyzed separately, were not correlated with their positions in the chronosequence (Table 1). Therefore, species composition of the sapling and seedling strata in successional forests were unrelated to stand age.

\section{Soil properties}

Successional stands were similar to each other in almost every soil property analysed (Table 3). Statistical analyses indicated no significant differences among stands in soil pH. All stands developed over strongly acid soils, with low $\mathrm{pH}$ values between 3.7 and 4.4. Total Carbon (C) contents were also similar across the chronosequence and indicated a high content of organic matter in all sites, including those recently disturbed. Values ranged from 36 to $49 \%$ with the lowest value recorded in MS2, a midsuccessional site (Table 3). Total nitrogen (N) contents of soils ranged from 1.3 to $2.2 \%$. The highest value was obtained in one late-successional stand, LS2, which had a correspondingly lower C:N ratio compared to all other stands. Early and mid-successional stands did not differ from later-successional stands with respect to total $\mathrm{N}$ (Table 3). However, inorganic $\mathrm{N}$ concentration, which represents the fraction available for plant uptake, was significantly higher in ES1, the youngest site in the chronosequence, decreased

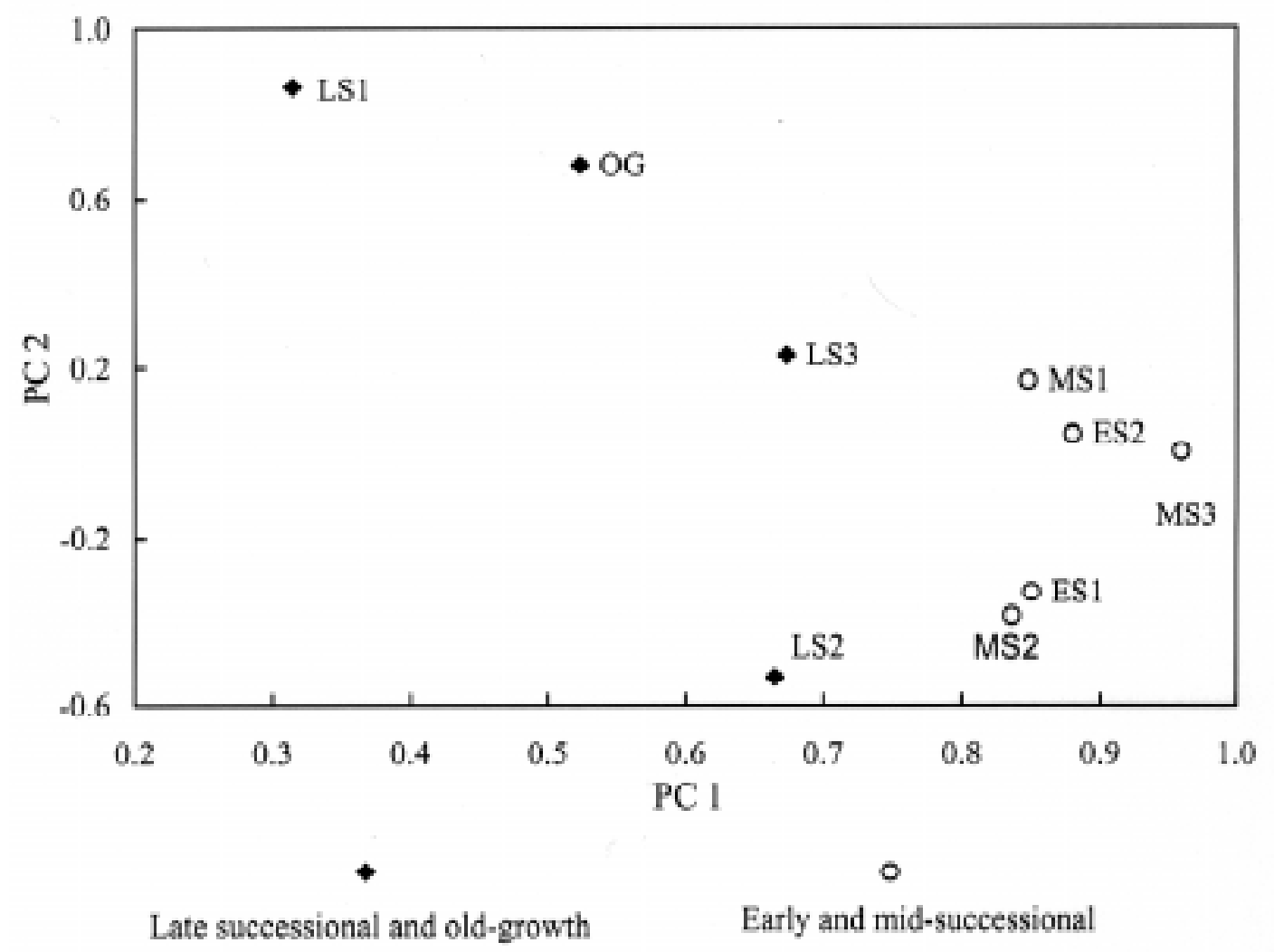

Fig. 7: Plot of the nine successional stands on the first two axes of a Principal Components Analysis (describing more than the $70 \%$ of total variation). Stand codes as in Table 1.

Gráfico de los dos primeros componentes principales (que dan cuenta de más del $70 \%$ de la variación total) para los nueve rodales sucesionales. Códigos de los rodales de acuerdo a la Tabla 1. 
in MS stands, and was higher again in the latesuccessional stand LS2 (Table 3), coinciding with the lowest $\mathrm{C} / \mathrm{N}$ ratio. Finally, bulk densities did not differ across sites.

\section{DISCUSSION}

\section{Limitations and power of the chronosequence approach}

Forest stands of different known age were taken here as representative of a temporal sequence, in an attempt to elucidate the patterns of recovery of lowland forests from stand-devastating fire and associated timber removal, a common form of human disturbance (Willson \& Armesto 1996). The most questionable assumption underlying the chronosequence approach is the validity of spacefor-time substitution (Pickett 1989). This assumption is supported here by at least two lines of evidence. First, all forests studied developed on very similar upland soils of glacial origin (Table 3) and, secondly, they were dominated by a floristically close species assemblage. Ordination of stands using PCA (Fig. 7) supports their strong floristic resemblance, particularly for early and mid-successional stands based on the relative importance of tree species, and for all stands in the chronosequence considering seedling and sapling composition (data not shown). Thus, it can reasonably be argued that stands subjected to fire disturbance in the study area exhibit strong similarity in their initial condition, with respect to both the colonizing assemblage of woody species and soil characteristics. However, late-successional stands $>100$ years old in northern Chiloé Island differed greatly in their composition of canopy tree species (Table 4, Fig. 7). The extent to which these present differences among stands may reflect particular site conditions or different initial conditions that influenced later successional trajectories remains poorly understood.

Differences in post-fire practices by local people remain a major source of uncertainties that may influence successional change. Among these 1ocal effects are timber and firewood extraction from disturbed sites, which influence residual woody detritus (Carmona et al. in press), and the impact of cattle grazing in open areas which varies among stands. With these effects in mind, generalizations from this chronosequence should be taken with caution. However, compared to other temperate regions of the world, the validity of space-for-time substitution in studies of succession in northern Chiloé forests seems to be reasonable on the grounds of the short history of intense human impact in the region (Armesto et al. 1994). Evidence from aerial photos indicates that all of the successional stands included in this study were part of extensive primary forests until the mid 1900's. Large scale clearing and forest burning in Chiloé Island became most prominent during the second half of the $20^{\text {th }}$ century (Willson \& Armesto 1996). Consequently, our study area lacks the numerous contingencies that characterize forest succession at sites subjected to several centuries of recurrent and sometimes undocumented human impact (Pickett 1989). This is a major limitation for applying the chronosequence approach to study forest recovery in eastern North America or Europe.

\section{Trends in tree species richness}

Results of this study did not support the hypothesis that an increase in species richness through mid succession should be followed by a decline in tree species richness in late-successional and oldgrowth stages in response to more intense interspecific competition for light and nutrients (Grime 1979, Tilman 1982, Huston 1994). In this successional chronosequence of North Patagonian forests in northern Chiloé Island, tree species richness increased steadily with stand age (Fig. 3A), with intermediate rather than high values in midsuccessional stands, and the highest number of tree species coexisting in the canopy of latesuccessional forests. The increase in tree species richness is accounted for, at least in part, by the incorporation of shade-tolerant species (Table 4), which gradually reach the forest canopy, resulting in a more even distribution of abundances (Fig. 6). The most important of these shade-tolerant trees that characterize the late-successional forest canopy are Podocarpus nubigena, Laureliopsis philippiana, and several species of slow-growing Myrtaceae. A similar trend has been postulated by Veblen et al. (1981) in coastal forests of Valdivia, and by Armesto \& Figueroa (1987) for coastal forests in the Chiloé Archipelago, where shade-tolerant trees become dominants in the canopy of old-growth forests. We did not find evidence for a total competitive replacement of pioneer, shade-intolerant trees over 200 years of successional time (e.g., Tilman 1982, 1988), even as shade-tolerant tree species increased in abundance. In fact, the canopy of oldgrowth forests in the study area can be described as a mosaic of shade-tolerant and intolerant tree species, in more even proportions than in earlysuccessional stands (Fig. 6). 


\section{Successional pathway}

The successional pattern documented in forests of Chiloé Island agrees with the model of Initial Floristic Composition of Egler (1954, see also Pickett et al. 1987). Egler (1954) proposed that species characteristic of all successional stages arrived to the disturbed site, but their relative importance gradually changed over time due primarily to differences in species' life cycles (e.g., Huston \& Smith 1987). Accordingly, data on seedling densities in this chronosequence showed little variation in floristic composition in relation to stand age (Fig. 4C). Both shade-tolerant and intolerant tree species coexisted in the understory of mid-successional stands (Fig. 4D). A slight decrease in shade-intolerant seedlings was associated with mid-successional stands, where the tree stratum was denser (Table 3 ). However, shadeintolerant seedlings continued to be present throughout the successional chronosequence. Furthermore, no trends were detected for species richness of saplings or seedlings during succession, in contrast to canopy trees (see above). Thus, over successional time, differences in species composition were only manifested in the composition of the forest canopy (Table 4, Fig. 7 ), suggesting that differences in life cycle attributes among seedling, sapling, and adult phases of tree species, such as contrasts in growth rates and levels of shade tolerance, become determinant for the observed differences in composition between late and early-successional stands (Fig. 7).

Data on seedling abundances and floristic composition suggests that colonization of successional areas by tree species is a rapid process following moderate fire disturbance. Given the lower number of tree species represented in the seedling stratum in early-successional stands (Table 3), there seems to be some limitation to the dispersal of propagules from nearby areas. Seeds of many tree species in Chiloé forests are actively dispersed by avian frugivores (Armesto \& Rozzi 1989, Willson et al. 1996, Salvande \& Armesto unpublished results). Incomplete burning of forests in our successional sites often leaves some standing dead and alive trees in the disturbed areas (Table 3) that may enhance the recruitment of bird-dispersed propagules by providing perches for avian frugivores (McDonnell \& Stiles 1983, Hernández 1995). The permanence of woody residues in recently disturbed sites may also facilitate the recruitment of tree species in successional sites (C. Papic \& J. Armesto unpublished results), because seedlings established on logs experience less variation in moisture contents than those growing on bare soil. Following the opening of the forest canopy, soils often become seasonally inundated and succession may be impaired (Willson \& Armesto 1996), except for seedling establishment on woody detritus. Hence facilitation of tree invasion (Pickett et al. 1987) by remaining structures from the pre-disturbance forest stand seems to be a critical condition for early succession in Chiloé. The loss of these structures, such as in clearcutting, should represent a major threat to early successional development.

\section{Species recruitment patterns}

Active regeneration of the majority of canopy trees was observed during the entire successional sequence in Chiloé forests. Drimys winteri, a tree species considered to be highly shade intolerant (Table 2, Donoso 1993, Armesto \& Fuentes 1988), was proportionally more abundant as seedling in the canopy of late-successional and old-growth forests, in contrast to early and mid-successional stands. This suggests that, although Drimys seeds are successfully dispersed into old-growth stands and they can germinate in the heterogeneous light environment of the forest understory, they are unable to survive to an older age there. Sapling densities, on the other hand, revealed a clear shift in dominance during the chronosequence from sun-loving Nothofagus and Drimys to typically shade-tolerant Amomyrtus (Fig. 4A). For Drimys, this suggests that juveniles, contrary to seedlings, have a limited ability to survive in the forest shade. Again, this result points to possible physiological differences between early and mature phases in the life cycle of tree species. Differences in life cycle attributes between seedling, juvenile and adult stages of the same tree species can be relevant for understanding forest dynamics, but have rarely been documented in the field (Clark et al. 1999).

In contrast to Drimys, Nothofagus was a more strict colonizer of open sites (Table 4, Fig. 4), reaching its greatest importance value in the canopy of early and mid-successional stands. This species is known to regenerate in large openings (Veblen et al. 1996, Armesto \& Figueroa 1987), but we show here that Nothofagus continues to be a major component of the forest canopy in 200 years-old stands. Seedlings and saplings of Nothofagus, however, were almost entirely lacking from late-successional and old-growth forests, hence confirming its assignment to the shadeintolerant species guild (Donoso 1993). Other shade-intolerant trees, however, such as Drimys 
winteri, maintained small populations of seedlings and saplings even in closed forests.

Pseudopanax laetevirens was the only tree species that, although represented by abundant numbers of seedlings in all stands, was unable to recruit successfully in the forest canopy at any successional stage (Fig. 4). The lack of saplings and adults of this tree species in the chronosequence is intriguing, given its high seedling densities in all successional phases. Where are the seed sources? Field observations at our study sites indicate that adults of this species are frequently seen as hemi-epiphytes on upper branches of giant, emergent individuals of Eucryphia cordifolia, Saxegothaea conspicua and Weinmannia trichosperma in late-successional and old-growth stands. The hemi-epiphytic growth habit of adult Pseudopanax contrasts with the broader distribution of seedlings in all substrates (Fig. 4B) and reinforces the need to examine physiological differences associated with seedling and adult phases of the plant's life cycle. Why Pseudopanax fails to recruit on the forest floor remains unknown and deserves further study.

The shade-tolerant character of species of Myrtaceae (Luma, Amomyrtus), noted in previous studies (Veblen et al. 1981, Armesto \& Figueroa 1987, Donoso 1993), is confirmed by the analysis of this successional chronosequence of Chiloé forests. Myrtaceous trees increased in importance in the canopy of older stands (Table 4, Fig. 4), and in the case of Amomyrtus, its seedlings were most abundantly represented in closed canopy stands in the chronosequence. Amomyrtus seedlings are also abundant in some early-successional sites (Fig. 4B), suggesting that seeds of this fleshyfruited tree species are actively disseminated by birds into recently disturbed sites and forest edges, where remnant snags and trees serve as perches for frugivorous birds (Armesto et al. 2001b). Seedlings of myrtaceaous trees grow slowly (Donoso 1993) and can only reach the canopy in late-successional and old-growth stands, which is also consistent with Egler's successional model.

\section{Soil properties and ecosystem functioning}

The main difference in soil properties among stands in the chronosequence was the greater availability of inorganic nitrogen in recently disturbed and old-growth stands compared to midsuccessional forests. Several studies have examined patterns of change in nutrient availability through succession and/or made predictions about expected successional changes in species composition and ecosystem functions (Bormann \& Lik- ens 1996, Tilman 1988, Peet 1992). In Chiloé forests, availability of inorganic nitrogen was higher in the most recently disturbed site (Table $3)$. This agrees with the prediction that disturbance, in this case a non-catastrophic fire, often promotes an initial release of nitrogen from recalcitrant organic matter (Matson et al. 1987, Anderson et al. 1988). Availability of nitrogen can also reflect the fact that plant demands are reduced in recently disturbed, open sites compared to growing forest stands. On the other hand, inorganic N availability was also higher in a late-successional forest (LS2) than in younger growing stands (MS2 and MS3). This patterns can also be predicted (Robertson \& Vitousek 1981, Vitousek et al. 1989) on the basis of the higher accumulation of organic matter expected in late-successional and oldgrowth forests. However, organic matter contents did not change significantly across this chronosequence, indicated by the percentage of soil carbon (Table 3), and hence this explanation is not likely to apply to Chiloé forests. The lower $\mathrm{C} / \mathrm{N}$ ratio of soils in the old-growth stand, associated with the greater abundance of Amomyrtus in the canopy (see below), may be related to higher mineralization rates and greater inorganic $\mathrm{N}$ availability documented in old-growth forest soils (Pérez et al. 1998). Active uptake by growing trees in mid-successional stands would account for the lower values of soil inorganic $\mathrm{N}$ with respect to late-successional forests.

The higher concentration of total $\mathrm{N}$ associated with a lower $\mathrm{C} / \mathrm{N}$ ratio of soils in stand LS2 (Table 3) can be explained by the increase in dominance by shade-tolerant tree species. These species are characterized by lower $\mathrm{C} / \mathrm{N}$ ratios of foliage, as has been shown for Luma apiculata and Laurielopsis philippiana (Pérez 1996). Values for soil $\mathrm{pH}$ are within the range of values reported for lowland temperate forests in the region (Pérez $1992,1996)$. The lowest $\mathrm{pH}$ was found in the latesuccessional site LS3, with a greater density of Tepualia stipularis (Table 4), a tree typically found in poorly drained sites. This suggests that soil conditions at this stand may differ slightly from the rest, associated with a higher water table and more acid substrate.

Results of this study showed that non-catastrophic fire disturbance, associated with forest burning by people, did not alter the soil ecosystem drastically, and allowed for the conservation of most critical soil properties (Table 3), and presumably microbial processes. The resilience soil conditions favored tree establishment and forest regeneration. The ability of forests subjected to moderate-intensity fire to recover rapidly contrasts with the effects of alternative land 
uses, which can also be observed in Chiloé Island. Where sites are not immediately abandoned after disturbance, but rather converted to grazing pastures, either permanently or temporarily following the removal of woody detritus, the initial release of soil inorganic $\mathrm{N}$ that follows forest fire (Table 3) may be rapidly lost from the ecosystem both as gas $\left(\mathrm{N}_{2} \mathrm{O}\right)$ emissions and via downstream leaching, resulting in longer recovery times. Results described here also differ from the larger alteration of soil processes documented by Likens and Bormann (1996), following clearcutting of northern hardwood forests in eastern North America. The similarity of soil properties across all successional ages in Chilean forests supports the idea that forest fragments in Chiloé Island may be fairly resilient to moderate fire disturbance, although the specific mechanisms that account for this resilience remain to be elucidated.

\section{Concluding remarks and implications for biodiversity}

Despite the large land cover of second-growth forests in southern Chile (CONAF-CONAMABIRF 1999), this is the first field study of successional patterns following anthropogenic disturbance in evergreen temperate rainforests of southern Chile. Evidence presented here supports the application of Egler's Initial Floristic Composition model to regeneration processes in the area. Profuse tree recruitment was recorded in early-successional sites. Regeneration did not seem to require the improvement of site conditions by pioneer shrubs or herbs, although facilitation of tree invasion by structural elements carried over from the pre-disturbance forest, such as snags, $\log$ s, as well as scattered surviving trees, which can serve as perches for frugivorous birds disseminating tree seeds, or as seedling establishment sites (C. Papic \& J. Armesto unpublished results), seems to be particularly critical.

The late-successional forests in the study area seem to be close to the old-growth condition for lowland North Patagonian forests, because of expected tree longevities (Veblen 1985). Accordingly, the natural disturbance regime in lowland forests of northern Chiloé Island would be associated with a canopy turnover rate of around 250 years. This estimate is close to Veblen's (1985) estimate of canopy turnover for central Chiloé. He attributed to large-scale windthrow a major role in the forest cycle in the absence of human disturbance (see also Donoso et al. 1985). Humans had their major impact on the forests of the study area in the second half of the $20^{\text {th }}$ century.
The regeneration of forests after human activities does not seem to be greatly impaired in the present landscape and at current rates of disturbance. An important remaining question, however, is what are the limits of resilience for these forest patches given the current trends in land use (Armesto et al. 1998). The regional reduction in forest area and increasing forest fragmentation (Willson et al. 1994), and isolation of remnant patches in the rural landscape are likely to reduce the resilience of disturbed forest stands, by altering seed inputs and soil system resilience. We predict, therefore, that as more patches are turned into pastures the ability of remaining forests fragments to maintain their biodiversity and ecosystem processes in the face of human disturbance will decrease.

As shown by the density of snags and old living trees in early and some mid-successional stands in the chronosequence, structural components of old-growth forests known to support an important fraction of stand biodiversity (e.g., Maser et al. 1988, Willson et al. 1994) are not totally loss from early successional forests. However, these 'legacies' from the pre-disturbance forests will be gradually lost in mid-successional stands due to increased rates of decomposition and faster tree growth (Carmona et al. in press). As more forested land becomes disrupted by fire and intense logging operations, old-growth and latesuccessional stands will become less represented in the landscape mosaic in comparison to midsuccessional stages (e.g., Franklin \& Forman 1987). Hence, we can expect further losses of these structural elements that may have cascading effects on biological diversity. We can also predict that biodiversity will decline faster as early and mid-successional stands become repeatedly disturbed, because more of these biological legacies, such as logs, snags, and old living trees will tend to disappear from the regenerating stands. In addition, as forest fragments become smaller and more isolated from one another, seed dispersal may become limiting for tree invasion. A delayed tree invasion can cause further losses of nutrients released by the initial disturbance (Table 3). These hypotheses can be tested by examining the abundance of sensitive components of forest biodiversity, such as birds that use large snags or big trees (Willson et al. 1994), in remnant forest patches in the mainland, north of Chiloé Island, where forests have been subjected to a more extended period of human impact, at least since the mid 1800's, and where forest fragments are generally smaller, structurally simpler, and more isolated in the rural landscape. 


\section{ACKNOWLEDGMENTS}

Field work was funded by the EC under the INCODC program (Framework 4), as part of SUCRE project (ERBIC-18CT97-0146), by FONDECYT (Chile) grant 1990946, and by a Presidential Chair in Science to JJA. Support from Millennium Nucleus P99-103-FICM, IAI-CRN 012, and grant FONDAP-FONDECYT 1501-0001 to the Center for Advanced Studies in Ecology \& Bioduversity, during the preparation of the manuscript is also appreciated. We thank the landowners that granted us access to their forests; A. Lara, A. Newton, G. Williams-Linera, and M. F. Willson for discussions and advice; E. Rivera, D. Dagyeli, I. Díaz, A. Gutiérrez, P. Naulin, C. Torrealba, P. Chacón, C. Segura, and A. Gabriel for assistance in the field and data analyses. This is a contribution to the Research Program of Estación Biológica "Senda Darwin", Ancud, Chiloé, Chile.

\section{LITERATURE CITED}

ANDERSON IC, JS LEVINE, MA POTH \& PJ RIGGAN (1988) Enhanced biogenic emissions of nitric oxide and nitrous oxide following surface biomass burning. Journal of Geophysical Research 93: 3893-3898.

ARMESTO JJ \& J FIGUEROA (1987) Stand structure and dynamics in the rain forest of Chiloé Archipelago, Chile. Journal of Biogeography 14: 367-376.

ARMESTO JJ \& ER FUENTES (1988) Tree species regeneration in a mid-elevation temperate forest in Isla Chiloé, Chile. Vegetatio 74: 151-159.

ARMESTO JJ \& R ROZZI (1989) Seed dispersal syndromes in the rain forest of Chiloé: evidence for the importance of biotic dispersal in a temperate rainforest. Journal of Biogeography 16: 219-226.

ARMESTO JJ, C DONOSO \& C VILLAGRÁN (1994) Desde la era glacial a la industrial: la historia del bosque templado chileno. Ambiente y Desarrollo (Chile) 10:66-72.

ARMESTO JJ, P LEÓN-LOBOS \& MTK ARROYO (1996a) Los bosques templados de Chile y Argentina: una isla biogeográfica. En: Armesto JJ, C Villagrán \& MTK Arroyo (eds) Ecología de los bosques nativos de Chile: 23-28. Editorial Universitaria, Santiago, Chile.

ARMESTO JJ, JC ARAVENA, C VILLAGRÁN, C PÉREZ \& G PARKER (1996b) Bosques templados de la Cordillera de la Costa. En: Armesto JJ, C Villagrán \& MTK Arroyo (eds) Ecología de los bosques nativos de Chile: 199-214. Editorial Universitaria, Santiago, Chile.

ARMESTO JJ, R ROZZI, C SMITH-RAMÍREZ \& MTK ARROYO (1998) Conservation targets in South American temperate forests. Science 282: 1271-1272.

ARMESTO JJ, R ROZZI \& J CASPERSEN (2001a) Temperate forests of North and South America. In: Chapin FS, OE Sala \& E Huber-Sannwald (eds) Global biodiversity in a changing environment. Scenarios for the 21st century: 223-249. Springer-Verlag, New York, New York.
ARMESTO JJ, I DÍAZ, C PAPIC \& MF WILLSON (2001b) Seed rain of fleshy and dry propagules in different habitats in the temperate rainforests of Chiloé Island, Chile. Austral Ecology 26: 311-320.

ARROYO MTK, L CAVIERES, A PEÑALOZA, M RIVEROS \& AM FAGGI (1996) Relaciones fitogeográficas y patrones regionales de riqueza de especies en la flora del bosque lluvioso templado de Sudamérica. In: Armesto JJ, C Villagrán \& MTK Arroyo (eds) Ecología de los bosques nativos de Chile: 7199. Editorial Universitaria, Santiago, Chile.

CARMONA MR, JC ARAVENA, CA PÉREZ \& JJ ARMESTO (in press) Coarse woody debris biomass in successional and primary temperate forests in Chiloé Island, Chile. Forest Ecology \& Management.

CLARK JS, B BECKAGE, P CAMILL, B CLEVELAND, J HILLERISLAMBERS, J LICHTER, J MCLACHLAN, J MOHAN \& P WYCKOFF (1999) Interpreting recruitment limitation in forests. American Journal of Botany 86: 1-16.

CONAF-CONAMA-BIRF (1999) Catastro y evaluación de recursos vegetacionales nativos de Chile. Corporación Nacional Forestal-Comisión Nacional del Medio Ambiente, Santiago, Chile. 90 pp.

DI CASTRI F \& ER HAJEK (1976) Bioclimatología de Chile. Vicerrectoría de Comunicaciones, Universidad Católica de Chile, Santiago, Chile. 129 pp.

DONOSO C, B ESCOBAR \& J URRUTIA (1985) Estructura y estrategias regenerativas de un bosque virgen de ulmo (Eucryphia cordifolia Cav.)-tepa (Laurelia philippiana Phil.) Looser en Chiloé, Chile. Revista Chilena de Historia Natural 58: 171-186.

DONOSO C (1993) Bosques templados de Chile y Argentina: variación, estructura y dinámica. Editorial Universitaria, Santiago, Chile. 484 pp.

EGLER FE (1954) Vegetation science concepts. I. Initial Floristic composition, a factor in old-field vegetation development. Vegetatio 4: 412-417.

FRANKLIN JF \& RTT FORMAN (1987) Creating landscape pattern by forest cutting: ecological consequences and principles. Landscape Ecology 1: 5-18.

GALLOWAY D (1996) Los líquenes del bosque templado de Chile. In: Armesto JJ, C Villagrán \& MTK Arroyo (eds) Ecología de los bosques nativos de Chile: 101112. Editorial Universitaria, Santiago, Chile.

GRIME JP (1979) Plant strategies and Vegetation Processes. John Wiley and Sons, New York, New York. 222 pp.

HERNÁNDEZ JF (1995) Efecto de los árboles percha sobre los patrones de lluvia de semillas y el establecimiento de plántulas: consecuencias para la sucesión secundaria del bosque de Chiloé. Tesis de Doctorado, Facultad de Ciencias, Universidad de Chile, Santiago, Chile. xiii +119 pp.

HUSTON MA (1994) Biological Diversity: the coexistence of species on changing landscapes. Cambridge University Press, Cambridge, United Kingdom. xix + $681 \mathrm{pp}$.

HUSTON MA \& TM SMITH (1987) Plant succession: life history and competition. American Naturalist 130: 168-198. 
LARA A, C DONOSO \& JC ARAVENA (1996) La conservación del bosque nativo de Chile: problemas y desafíos. In: Armesto JJ, C Villagrán \& MTK Arroyo (eds) Ecología de los bosques nativos de Chile: 335362. Editorial Universitaria, Santiago, Chile.

LIKENS GE \& FH BORMANN (1996) Biogeochemistry of a forested ecosystem. Second edition. SpringerVerlag, New York, New York. xii +159 pp

MAGURRAN AE (1988) Ecological diversity and its measurements. Princeton University Press, Princeton, New Jersey.179 pp.

MASER C, RF TARRANT, JM TRAPPE \& JF FRANKLIN (1988) From the forest to the sea: A story of fallen trees. United States Department of Agriculture, Forest Service, Bureau of Land Management, Washington, District of Columbia. 153 pp.

MATSON PA, PM VITOUSEK, J EWEL, ML MAZZARINO \& GP ROBERTSON (1987) Nitrogen transformation following tropical forest felling and burning on a volcanic soil. Ecology 68: 491-502.

MCDONELL MJ \& EW STILES (1983) The structural complexity of old field vegetation and the recruitment of bird-dispersed plant species. Oecologia 56: 109116.

MYERS N, RA MITTERMEIER, GAB DFONSECA \& J KENT (2000) Biodiversity hotspots for conservation priorities. Nature 403: 853-858.

OLIVER CD \& BC LARSON (1990) Forest stand dynamics. McGraw-Hill, New York, New York. 467 pp.

OLSON DM \& E DINERSTEIN (1998) The Global 200: a representation approach to conserving the Earth's most biologically valuable ecoregions. Conservation Biology 12: 502-515.

PEET RK (1992) Community structure and ecosystem function. In: Glenn-Lewis DC, RK Peet \& TT Veblen (eds) Plant succession: 103-151. Chapman and Hall, London, United Kingdom.

PÉREZ C (1992) Los bosques de "olivillo" (Aextoxicon punctatum R. et Pav.) de la Cordillera de La Costa de Chile: interacción clima-suelo-vegetación. Tesis de Doctorado, Facultad de Ciencias, Universidad de Chile, Santiago, Chile. $x x+157$ pp.

PÉREZ CA (1996) Los procesos de descomposición de la materia orgánica de bosques templados costeros: interacción entre suelo, clima y vegetación. In: Armesto JJ, C Villagrán \& MTK Arroyo (eds) Ecología de los bosques nativos de Chile: 301-315. Editorial Universitaria, Santiago, Chile.

PÉREZ CA, LO HEDIN \& JJ ARMESTO (1998) Nitrogen mineralization in two unpolluted old-growth forest of contrasting biodiversity and dynamics. Ecosystems 1: 361-373.

PICKETT STA, SL COLLINS \& JJ ARMESTO (1987) Models, mechanisms and pathways of succession. Botanical Review 53: 335-371.

PICKETT STA (1989) Space-for-time substitution as an alternative to long-term studies. In: Likens GE (ed) Long-term studies in ecology: approaches and alternatives: 110-135. Springer-Verlag, New York, New York.
ROBERTSON GP \& PM VITOUSEK (1981) Nitrification potentials in primary and secondary succession. Ecology 67: 376-386.

STOKES MA \& TL SMILEY (1968) An introduction to tree-ring dating. University of Arizona Press, Tucson, Arizona. xvii +74 pp.

TILMAN D (1982) Resource competition and community structure. Princeton University Press, Princeton, New Jersey. $\mathrm{xi}+296 \mathrm{pp}$.

TILMAN D (1988) Plant strategies and the dynamics and structure of plant communities. Princeton University Press, Princeton, New Jersey. xi +360 pp.

VEBLEN TT (1985) Forest development in tree-fall gaps in the temperate rain forests of Chile. National Geographic Research 1: 161-184.

VEBLEN TT, C DONOSO, FM SCHLEGEL \& B ESCOBAR (1981) Forest dynamics in south-central Chile. Journal of Biogeography 8: 211-247.

VEBLEN TT, FM SCHLEGEL \& JV OLTREMARI (1983) Temperate broad-leaved evergreen forests of South America. In: Ovington JD (ed) Temperate broad leaved evergreen forests: 5-31. Elsevier Science Publishers, Amsterdam, The Netherlands.

VEBLEN TT \& PB ALABACK (1996) A comparative review of forest dynamics and disturbance in the temperate rainforests of North and South America. In: Lawford RG, PB Alaback \& E Fuentes (eds) High latitude rain forests and associated ecosystems of the west coast of the Americas: climate, hydrology, ecology and conservation: 173-213. Springer-Verlag, New York.

VEBLEN TT, T KITZBERGER, BR BURNS \& AJ REBERTUS (1996) Perturbaciones y dinámica de regeneración en bosques andinos del sur de Chile y Argentina. In: Armesto JJ, C Villagrán \& MTK Arroyo (eds) Ecología de los bosques nativos de Chile: 169-198. Editorial Universitaria, Santiago, Chile.

VILLAGRÁN C \& LF HINOJOSA (1997) Historia de los bosques del sur de Sudamérica, II: análisis fitogeográfico. Revista Chilena de Historia Natural 70: 241-267.

VITOUSEK PM, PA MATSON \& KV CLEVE (1989) Nitrogen availability and nitrification during succession: primary, secondary and old-field seres. Plant and Soil 115: 229-239.

WILLSON MF, TL DE SANTO, C SABAG \& JJ ARMESTO (1994) Avian communities of fragmented south-temperate rainforests in Chile. Conservation Biology 8: 508-520.

WILLSON MF, C SMITH-RAMÍREZ, C SABAG \& JF HERNÁNDEZ (1996) Mutualismos entre plantas y animales en bosques templados de Chile. In: Armesto JJ, C Villagrán \& MTK Arroyo (eds) Ecología de los bosques nativos de Chile: 251-264. Editorial Universitaria, Santiago, Chile.

WILLSON MF \& JJ ARMESTO (1996) The natural history of Chiloé: on Darwin's trail. Revista Chilena de Historia Natural 69: 149-161. 


\section{APPENDIX 1}

Density ( $\mathrm{n}$, number of stems ha $\mathrm{a}^{-1}$ ) and basal area (BA in $\mathrm{m}^{2} \mathrm{ha}^{-1}$ ) for tree species in early (ES), mid (MS), late-successional (LS) and old-growth (OG) forests of northern Chiloé Island. Stand codes as in Table 1

Densidad (n, número de fustes ha-1) y área basal (BA en $\mathrm{m}^{2} \mathrm{ha}^{-1}$ ) para las especies arbóreas en bosques sucesionales tempranos (ES), intermedios (MS), avanzados (LS) y rodales antiguos (OG) el norte de la isla de Chiloé. Códigos de rodales de acuerdo a Tabla 1

\begin{tabular}{|c|c|c|c|c|c|c|c|c|c|}
\hline \multirow[b]{2}{*}{ Trees } & ES1 & ES2 & MS1 & MS2 & MS3 & LS1 & LS2 & LS3 & OG \\
\hline & $\mathrm{n} \quad \mathrm{BA}$ & $\mathrm{n} \quad \mathrm{BA}$ & $\mathrm{n} \quad \mathrm{BA}$ & $\mathrm{n} \quad \mathrm{BA}$ & $\mathrm{n} \quad \mathrm{BA}$ & $\mathrm{n} \quad \mathrm{BA}$ & $\mathrm{n} \quad \mathrm{BA}$ & $\mathrm{n} \quad \mathrm{BA}$ & $\mathrm{n} \quad \mathrm{BA}$ \\
\hline Amomyrtus luma & 0.3 & 0.0 & 0.0 & 640 & 580 & 70 & $1280 \quad 12.1$ & 440 & 100 \\
\hline Amomyrtus meli & 0.0 & 0.0 & 0.0 & 0.2 & 0.0 & 0.0 & $\begin{array}{ll}0 & 0.0\end{array}$ & 0.0 & 0 \\
\hline Crinodendron hookerianum & 0.0 & 0.0 & 0.0 & 0.0 & 0.0 & 160 & 0.1 & 0.1 & 120 \\
\hline Caldcluvia paniculata & 0.0 & 0.0 & 0.0 & 0.1 & 220 & 470 & $20 \quad 0.1$ & 210 & 160 \\
\hline Drimys winteri & 1.3 & 120 & 1010 & 1760 & 1510 & 180 & 38031.6 & 10.7 & 570 \\
\hline Eucryphia cordifolia & 0.0 & 0.0 & 0.0 & 13.3 & 0.0 & 0.0 & $20 \quad 0.4$ & 0.0 & 0 \\
\hline Gevuina avellana & 0.0 & 0.0 & 0.0 & 0.2 & 0.0 & 0.0 & $\begin{array}{ll}60 & 0.7\end{array}$ & 0.3 & 30 \\
\hline Laureliopsis philippiana & 0.0 & 0.0 & 0.0 & 0.7 & 0.0 & 0.0 & 36013.1 & 1.6 & 30 \\
\hline Myrceugenia parvifolia & 0.0 & 0.0 & 0.0 & 0.0 & 0.2 & 0.0 & $40 \quad 0.1$ & 0.3 & 20 \\
\hline Nothofagus nitida & 0.0 & 2.6 & 1021 & 260 & 520 & 190 & 60 & 22.3 & 90 \\
\hline Pseudopanax laetevirens & 0.0 & 0.0 & 0.4 & 0.0 & 0.9 & 0.0 & 0.0 & 0.1 & 0.0 \\
\hline Podocarpus nubigena & 0.3 & 0.0 & 0.0 & 0.0 & 11.1 & 560 & 0.0 & 200 & 360 \\
\hline Saxegothaea conspicua & 0.0 & 0.0 & 0.0 & 0.5 & 1.9 & 0.2 & 0.0 & 28.6 & 30 \\
\hline Tepualia stipularis & 0.0 & 0.0 & 300 & 0.0 & 140 & 1280 & 0.0 & 270 & 550 \\
\hline Weinmannia trichosperma & 0.0 & 1.0 & 0.0 & 0.0 & 0.0 & 10 & 0.0 & 8.3 & 21.2 \\
\hline Samplings & $\mathrm{n}$ & $\mathrm{n}$ & $\mathrm{n}$ & $\mathrm{n}$ & $\mathrm{n}$ & $\mathrm{n}$ & $\mathrm{n}$ & $\mathrm{n}$ & $\mathrm{n}$ \\
\hline Amomyrtus luma & 540 & 600 & 44 & 2690 & 8440 & 620 & 2340 & 3030 & 3900 \\
\hline Amomyrtus meli & 400 & 40 & 0 & 71 & 0 & 0 & 20 & 0 & 50 \\
\hline Crinodendron hookerianum & 0 & 0 & 0 & 0 & 440 & 2000 & 180 & 0 & 100 \\
\hline Caldcluvia paniculata & 0 & 80 & 0 & 429 & & 160 & 580 & 200 & 550 \\
\hline Drimys winteri & 1060 & 1960 & 2109 & 810 & 920 & 200 & 0 & 133 & 1850 \\
\hline Eucryphia cordifolia & 0 & 0 & 377 & 810 & 0 & 0 & 180 & 0 & 0 \\
\hline Gevuina avellana & 0 & 0 & 0 & 429 & 40 & 0 & 60 & 33 & 0 \\
\hline Laureliopsis philippiana & 0 & 0 & 0 & 405 & 0 & 0 & 920 & 33 & 50 \\
\hline Myrceugenia parvifolia & 320 & 0 & 22 & 0 & 2040 & 40 & 740 & 233 & 1700 \\
\hline Nothofagus nitida & 180 & 7640 & 3530 & 95 & 640 & 40 & 0 & 333 & 0 \\
\hline Pseudopanax laetevirens & 0 & 80 & 155 & 0 & 0 & 0 & 0 & 100 & 0 \\
\hline Podocarpus nubigena & 380 & 0 & 178 & 0 & 1920 & 1020 & 0 & 533 & 50 \\
\hline Saxegothaea conspicua & 20 & 0 & 0 & 24 & 80 & 120 & 0 & 266 & 500 \\
\hline Tepualia stipularis & 120 & 0 & 2664 & 0 & 200 & 180 & 0 & 0 & 850 \\
\hline Weinmannia trichosperma & 0 & 200 & 44 & 24 & 0 & 0 & 0 & 0 & 0 \\
\hline Seedlings & $\mathrm{n}$ & $\mathrm{n}$ & $\mathrm{n}$ & $\mathrm{n}$ & $\mathrm{n}$ & $\mathrm{n}$ & $\mathrm{n}$ & $\mathrm{n}$ & $\mathrm{n}$ \\
\hline Amomyrtus luma & 10208 & 5390 & 232 & 10250 & 8730 & 27763 & 19773 & 10367 & 11640 \\
\hline Amomyrtus meli & 0 & 898 & 0 & 0 & 1027 & 0 & 0 & 0 & 0 \\
\hline Crinodendron hookerianum & 0 & 0 & 0 & 0 & 0 & 5553 & 0 & 0 & 1225 \\
\hline Caldcluvia paniculata & 0 & 1797 & 0 & 0 & 2054 & 8329 & 989 & 1555 & 4288 \\
\hline Drimys winteri & 3573 & 4491 & 2089 & 3588 & 1541 & 26375 & 16807 & 4665 & 10415 \\
\hline Eucryphia cordifolia & 3063 & 1797 & 929 & 3075 & 1027 & 0 & 989 & 518 & 0 \\
\hline Gevuina avellana & 1021 & 898 & 0 & 1025 & 0 & 0 & 5932 & 0 & 0 \\
\hline Luma apiculata & 0 & 0 & 696 & 0 & 0 & 0 & 0 & 0 & 0 \\
\hline Laureliopsis philippiana & 3573 & 0 & 0 & 3588 & 0 & 0 & 12852 & 1037 & 1838 \\
\hline Myrceugenia parviflora & 0 & 0 & 0 & 0 & 6162 & 1388 & 4943 & 3628 & 4901 \\
\hline Myrceugenia planipes & 0 & 0 & 0 & 0 & 0 & 0 & 2966 & 0 & 0 \\
\hline Nothofagus nitida & 1021 & 7635 & 1857 & 1025 & 1027 & 9717 & 989 & 518 & 1225 \\
\hline Podocarpus nubigena & 1531 & 7186 & 232 & 1538 & 7189 & 23599 & 0 & 6220 & 7964 \\
\hline Pseudopanax laetevirens & 6635 & 1347 & 464 & 6663 & 4108 & 27763 & 9886 & 6738 & 7964 \\
\hline Saxegothaea conspicua & 0 & 898 & 0 & 0 & 4622 & 0 & 0 & 3628 & 4288 \\
\hline Tepualia stipularis & 0 & 3144 & 1625 & 0 & 514 & 0 & 0 & 0 & 0 \\
\hline Weinmannia trichosperma & 0 & 3144 & 0 & 0 & 0 & 1388 & 0 & 0 & 0 \\
\hline
\end{tabular}

